\title{
"It just goes to kill Ticos": national market regulation and the political ecology of farmers' pesticide use in Costa Rica
}

\author{
Ryan E. Galt ${ }^{1}$ \\ University of California, Davis, USA
}

\section{Introduction}

In 2003 I visited many Costa Rican farms and surveyed and interviewed Tico ${ }^{2}$ farmers, produce buyers, and agrochemical salespeople while conducting fieldwork for my dissertation. On a rare, cloud-free morning I visited the farm of Manuel, ${ }^{3}$ who produces chayote - a Central American cucurbit typically grown on a trellis - for export in addition to other vegetables sold on the national market. He showed me that he washes his chayote in clean wash bins dedicated solely to the task, as required by the Costa Rican export firm that contracts with him and ships his and hundreds of other chayote farmers' produce to the United States, Canada, and Europe. As we walked across his farm and through fields of green beans and trellises of chayote, we came upon workers washing green beans for the national market, distinguishable by their larger size from the vainica fina (fine green beans) grown for export. They were washing them in a 50gallon drum known as an estañón, which almost all farmers in the area use for mixing pesticides (Figure 1). When I expressed shock at this, he said adamantly that he would never do that with his export chayote. Besides, he assured me, the estañón had been rinsed well. The reason for not washing the national market green beans in the export chayote wash bin is that he used pesticides on the green beans that are not permitted on chayote for export. There is some risk that these residues would contaminate the export wash bin, transfer to the exported chayote, and be found to violate pesticide residue standards of importing nations.

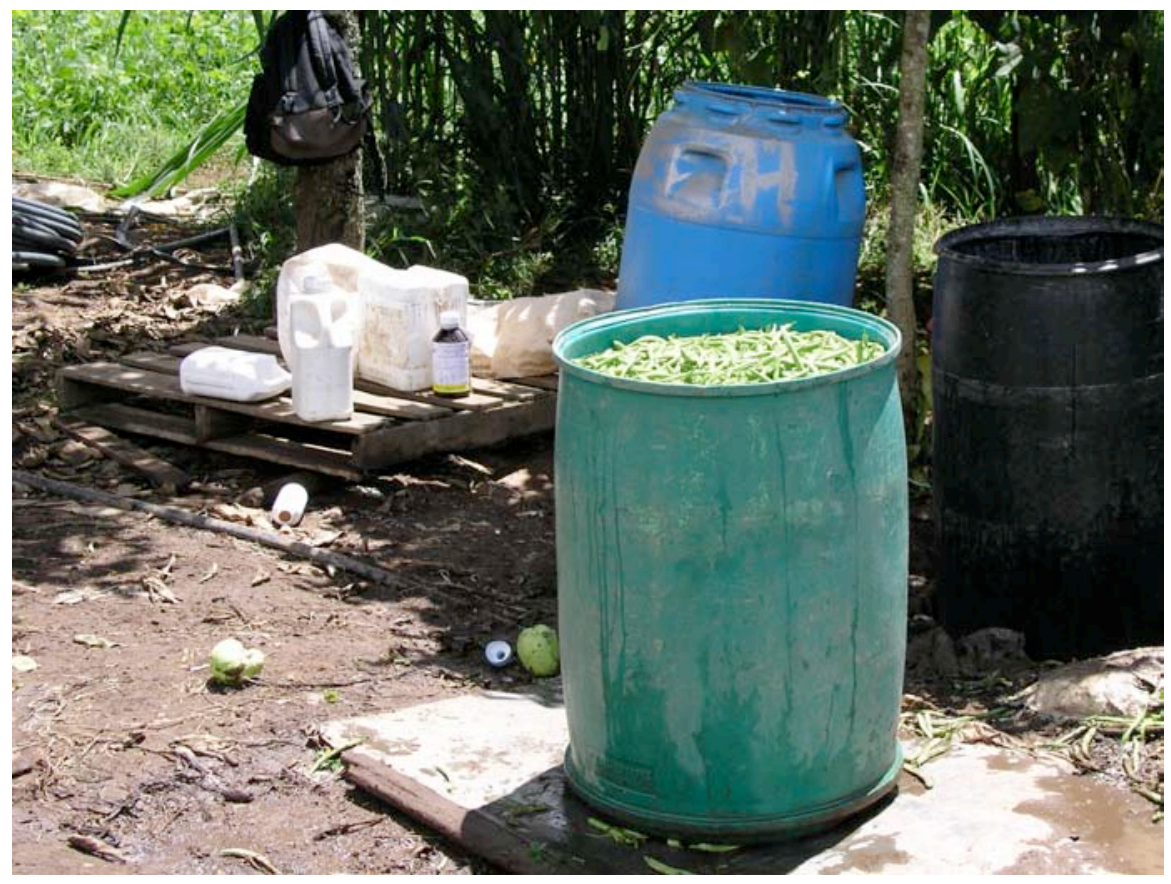

Fig. 1: Green beans for national market being washed in a pesticide mixing tank (author).

\footnotetext{
${ }^{1}$ Assistant Professor of Agricultural Sustainability and Society, Department of Human and Community Development \& Agricultural Sustainability Institute; University of California, 1309 Hart Hall, One Shields Ave., Davis, CA 95616, USA. Email: regalt "at" ucdavis.edu. I gratefully acknowledge funding from a Fulbright IIE Student Fellowship and a MacArthur Foundation Global Studies Fellowship from the Global Studies Program at the University of WisconsinMadison. I thank the Eric Wolf Prize committee members and Karl Zimmerer, Matthew Turner, Jamie Peck, Jane Collins, Brad Barham, Jennifer Gardner, Colleen Hiner, Christie McCullen, and Margaret MacSems for their comments on various versions of this manuscript, and Mara Goldman and Raoul Liévanos for conversations influencing my thinking. Errors and shortcomings remain my own. This paper was awarded the Eric Wolf Prize, Political Ecology Society, 2008.

${ }^{2}$ Costa Ricans refer to themselves affectionately as "Ticos." The name is derived from their common use of a diminutive form different from that used by most Spanish speakers.

${ }^{3}$ All farmers' names have been changed in the interest of confidentiality.
} 
This double standard in the treatment of export and national market produce serves to illustrate the topic of this paper: a comparison of pesticide use as it relates to residues on national market and exported vegetables in Costa Rica. Using a political ecology approach, I seek to understand the extent to which this double standard exists in farmers' pesticide use practices, and to link this double standard both to its origins in the uneven development of pesticide regulations, and to its potential effects on consumers in Costa Rica and developing countries generally.

Increasingly in political ecology and agri-food studies we are implored to link understandings of production to those of consumption, or at least to devote greater attention to issues of consumption (Bryant and Goodman 2004; Cook 2006; DuPuis 2000; Goodman and DuPuis 2002; Guthman and DuPuis 2006; Heyman 1994, 2005; Lockie and Kitto 2000; Wilk 2006). While many focusing on agriculture have rushed to explore the meanings and consequences of alternative food production and consumption, I emphasize that much remains to be understood about production-consumption issues in agrochemically-dependent, industrial farming systems, especially in developing countries.

One such issue in conventional production systems is pesticide residues in food. While not seen as the most problematic impact of pesticides - certainly farm worker exposure (Chávez 1993) and pesticide drift in populated areas and especially near schools (Gutiérrez C. 2003; Harrison 2006; Rojas 2004; Weppner et al. 2005) are larger health risks than residues on food - pesticide residues raise concerns since they can affect the entire population. As such, they have been hotly debated for over a century (Whorton 1974) and are featured prominently in Silent Spring (Carson [1962] 1994). Pesticide residues remain an important public concern and as such are a primary driver, at least in industrialized countries, of the increased consumption of certified organic food. In developing countries, there are many indications of consumer concern (Díaz-Knauf et al. 1993; Dinham 2003), and we are likely to see interesting developments in the organic and supermarket sectors in these countries in the near future.

A great deal of research focuses on pesticide residues, and pesticide use as it relates to residues, in developing countries. The studies to date follow three general contours: (1) residue testing by analytical chemists which generally shows high levels of pesticides on national market produce (Carazo et al. 1984; Centre for Science and Environment 2006; Chang et al. 2005; Dogheim et al. 1990; Ip 1990); (2) assessments of pesticide use practices, emphasizing farmers' lack of caution for both their own safety and that of consumers of their products (e.g., Abeysekera 1988; García 1999; Guan-Soon and Seng-Hock 1987; Heong et al. 1995; Hui et al. 2003; Yen et al. 1999; Zaidi 1984); and (3) critical social science — generally using political economy of agriculture or political ecology approaches — that emphasizes a neocolonial environmental injustice by relating pesticide use and problems to the broader political economy. The studies in this last category almost always conclude that integration of agricultural production into export markets increases pesticide use, thereby subjecting local populations and environments to high levels of pesticide contamination (e.g., Conroy et al. 1996; Mo 2001; Murray 1991, 1994; Murray and Hoppin 1992; Stewart 1996; Stonich 1993; Thrupp 1991a, 1991b; Thrupp et al. 1995). This work informed by political economy remains mostly silent on national market production.

Why, then, pursue a political ecology of pesticide residues? Approaching the topic of pesticide residues on food in developing countries from a political ecology perspective raises a number of unanswered scholarly and policy-relevant concerns. Two are addressed here. First, why do farmers use pesticides in a manner that causes high levels of residues on produce? Can this be attributed to lack of education, as it is often done, or more to political economic factors related to the capitalist mode of production and/or the ecological underpinnings of agriculture? Second, what are the effects of uneven pesticide residue regulations on farmers' pesticide use, i.e., how do different markets - often with different types and strengths of pesticide regulation - affect farmers' pesticide use, and, by inference, the resulting exposure of different populations fed by different market segments?

The answers to these questions are important to most everyone who eats food in developing countries, but, unfortunately, most of the studies done on pesticide use fail to provide adequate answers. The first two types of studies identified above — residue studies and those emphasizing lack of caution generally conclude, with little supporting evidence, that pesticide problems stem from ignorance, so education or training of farmers is the correct answer (e.g., Rodríguez Solano 1994). This thinking, propelled by "naïve sociology" based on unsound assumptions about social relationships and the devaluation of nonscientific knowledge (cf. Wynne 1989), informs the "safe use" paradigm that promotes farmer training with an emphasis on protective clothing, recommended pesticide handling, and label reading. Murray (1994; Murray and Taylor 2000) has contributed valuable critiques of safe use campaigns, which have been largely ineffective in tackling most pesticide problems, and fail to provide and promote needed alternatives to the intentional release of toxins into the environment.

Political ecology can play a potentially valuable role in answering the questions about pesticide residues posed above because of its attention to a broadly-defined political economy — including market integration, local power relations, and control over resources — and the ecological underpinnings of agricultural production (e.g., Blaikie 1985; Blaikie and Brookfield 1987; Carney 2004; Grossman 1998; Zimmerer 1991). Political ecology's potential to answer these questions also derives from its common use of mixed methods, often blending qualitative and quantitative understandings (Fairhead and Leach 1996; 
Robbins 2003). Political ecology's attentiveness to ecological systems (Scoones 1999; Walker 2005; Zimmerer 1996), including the organisms affected by land management and their interactions, is also very important. Spraying pesticides is an ecological intervention into the agroecosystem; the pests, beneficial organisms, soil biota, and crops present in the system interact as ecological agents and, together with socioeconomic factors, jointly influence pesticide use decisions (Galt 2008).

I highlight the potential of political ecology to address these pesticide residue consumption questions because, as noted above, political ecologists have focused on pesticide issues in developing countries, but almost always in the context of agricultural exports. Indeed, I would argue that political ecology has not tackled important pesticide questions in national market crops because the dominant narrative in the critical literature about markets and pesticide intensity in developing countries — that pesticides are used more heavily on export crops while national market crops are sprayed little — makes the very idea of high pesticide use and residues on national market produce inconceivable (Galt 2008). The focus on pesticide use in export crops means that in most critical studies, postcolonial injustice in the global South appears in monolithic form and is informed by a world-systems perspective (cf. Wallerstein 1974): developing countries, and especially farmers and farm workers in them, bear a disproportionate environmental and health burden by producing environmentally damaging and pesticide-intensive food products destined for the industrialized world.

With the almost exclusive focus on export production and a lingering monolithic view of pesticide injustices in the world system, significant gaps in political ecological knowledge exist concerning how farmers use pesticides on food crops destined for developing countries' national markets, i.e., the causes behind high levels of residues that are often detected, and about potential solutions. To address this gap, this article focuses on Costa Rican farmers' pesticide use in relation to potential residues on fresh vegetables for the domestic market, and uses export farmers' practices as a comparative reference point because of tighter control over pesticide use in that market segment (Galt 2007). Using primary data from a farmer survey and interviews conducted in Costa Rica, I argue that while pesticide rationalization has occurred to some extent on export vegetables, pesticide use on national market vegetables remains basically unregulated, and national market vegetable farmers exercise considerably less caution with pesticide use as it relates to residues. A substantial minority of national market farmers' pesticide use likely results in levels of pesticide residues that can cause acute poisonings for consumers. This and a review of secondary data lead me to highlight an unequal burden of pesticide residues from uneven regulation: on average, exported vegetables likely have lower levels of residues than vegetables that stay in Costa Rica.

The paper proceeds as follows. I first introduce the concept of a regulatory double standard for pesticide residues and support it with secondary data showing the importance of aesthetic requirements and pesticide residue problems that exist in developing countries. I then examine the situation in Costa Rica by considering the legal and regulatory framework affecting pesticide residues in various market segments. A discussion of methods follows. I then explore primary data on pesticide use practices from 13 months of fieldwork in Costa Rica, including data from surveys of farmers producing chayote, green bean, and squash for the national market. These data are compared to the practices of export farmers of the same crop. The discussion and conclusions section critiques the "farmer ignorance thesis" as an explanation of high residue levels and proposes a political ecological understanding that emphasizes the "simple reproduction squeeze" (cf. Watts 1983) facing national market vegetable farmers; points to further considerations about agro-food governance in different market segments and the influence of food-based social movements in developing countries; and explores health and equity aspects of the pesticide residue double standard through an engagement with and extension of environmental justice concepts.

\section{A regulatory double standard with consequences for pesticide residue consumption}

"Social regulation," or, in Marxian and Polanyian terms, "extra-economic regulation," refers to "those forms of regulatory control that are not directly concerned with the control of markets or other specific aspects of economic life, but instead aim to protect people or the environment from the damaging consequences of industrialization" (Hawkins 1989: 663). Pesticide residue regulation is a prime example of extra-economic regulation. When viewed globally, there is an uneven spatiality of pesticide residue regulation by national markets: the industrialized world/global North has relatively strong regulations over pesticide residues in food, while the developing world/global South lacks many regulations. ${ }^{4}$ Despite the valid critiques that point out the serious flaws of the U.S. Food and Drug Administration's pesticide residue testing system for imported produce (GAO 1979; Wargo 1998), it should be recognized that U.S. and other industrialized countries' pesticide regulations and enforcement create "regulatory risk" to which Costa Rican exporters and export farmers respond by trying to avoid illegal pesticide residues, although in the context of limited resources and imperfect understandings (Galt 2007). In contrast, this regulatory risk is largely absent in developing country markets since enforcement of pesticide residue standards, if they exist, is minimal

\footnotetext{
${ }^{4}$ I am construing "regulation" broadly to include the creation and enforcement of rules governing behaviors and products.
} 
(Dinham 2003; Ecobichon 2001; El Sebae 1993).

Authors in industrialized nations, especially scholars using a political economy perspective who have examined pesticide problems in agro-exports from Latin America, seldom recognize or acknowledge the double standard of stronger export regulation and weaker national market regulation. Arbona (1998) provides one of the few exceptions with her work on pesticide use in Almolonga, an area in Guatemala that produces potato, carrot, onion, cabbage, beet, celery, lettuce, and radish for national and Central American markets. She notes that in Almolonga, unlike in the export pea growing areas, the idea of reducing or eliminating pesticide use through alternative agricultural practices

has been difficult to introduce. One of the main objectives of these initiatives elsewhere has been reduction of pesticide residues in food, initiatives sparked by the repeated failures and losses of Guatemalan vegetable exports interdicted on the international market. Historically, Almolongueño farmers, whose principle markets - national, Mexican, and Central American - have less stringent import regulations, have not had to introduce changes in their intensive use of pesticides (Arbona 1998: 61-62).

In this case, the export market leads to action to rationalize pesticide use, while the national market does not. Similarly, while noting improvements in pesticide use and control in Senegal's agro-export sector, Williamson (2003: 13) mentions that "Senegalese public servants have pointed out the double standards existing between food safety requirements on produce exported to Europe and national capacity and monitoring of residues in local vegetables and food grains." In Costa Rica, Kopper (2002: 1) observes:

Since 1997, under pressure from food safety agencies in the United States of America, Costa Rica's main export market, the government and the country's large-scale exportoriented industries have been undergoing major efforts to ensure compliance with new, stricter standards on fresh produce. While these efforts have been crowned with success, much remains to be done to ensure a safer food supply to the local market.

The conceptualization of this regulatory double standard is complicated somewhat by the rapid expansion of agroindustries and supermarket chains in developing countries (Balsevich et al. 2003; Berdegué et al. 2005; Dugger 2004; Reardon and Barrett 2000). Local supermarkets now "equal or exceed the importance of non-traditional exports in the Central American FFV [fresh fruit and vegetable] sector," although the effects of this transformation are much less studied (Berdegué et al. 2005: 256). In Costa Rica, about 50 percent of food retail sales went through 227 supermarkets in 2002 (Berdegué et al. 2005: 256-7). As in industrialized countries, consumers in developing countries are increasingly concerned about pesticide residues and some want assurance that the produce they eat will not poison them (Díaz-Knauf et al. 1993; Dinham 2003; Reardon et al. 2001). Supermarkets seem poised to gain market share by stoking these concerns. Some farmers claim that supermarkets have played to consumer fears about biological and pesticide contamination by claiming to offer "better quality" produce than at farmers' markets. ${ }^{5}$ While agrifood researchers have tackled the consequences of supermarket expansion in industrialized nations (Murdoch et al. 2000), an unaddressed research question in Central America is how supermarkets' expansion "is affecting, if at all, the quality and safety standards of the FFV sold and consumed in the region" (Berdegué et al. 2005: 256). What this means for the regulatory double standard - if, for example, supermarkets in developing countries create mechanisms of control in contract farming that are similar to exporters, or attempt to claim quality while making minimal adjustments to production practices - remains to be seen. While I provide some data on these relationships below, it forms only a minor consideration in this paper.

Instead of its marginal or non-existent place in political ecological work on agriculture and food in developing countries, I argue that the uneven spatiality of pesticide regulation, explored here as a double standard, is an important facet of a political ecology of globalization (cf. Bebbington and Batterbury 2001). It resides at the intersection of economic globalization and systematic differences in privilege and marginality in the world system (cf. Wolf 1982), the linkages between broader political economic structures and farmers' environmental management, and unequal environmental contamination, toxic body burdens, and health implications between North and South.

\section{Pesticide residues on produce in developing countries}

The regulatory double standard arises from similar aesthetic requirements in capitalist markets in both North and South, but much stronger regulatory power in the North. Although those writing in the global North from a political economy perspective rarely acknowledge it, pesticide use is generally very high on national market vegetables in developing countries. Research on these markets has concluded that aesthetic qualities are very important (Dinham 2003; Grossman 1998; Jungbluth 1997; Medina 1987), and the high value of horticultural crops makes it likely that they will be produced with high levels of agrochemical inputs (Fernandez-Cornejo, Jans et al. 1998; Galt 2008; Gockowski and Ndoumbe 2004). Grossman (1998: 197) notes, "Vincentian farmers producing for sale in local markets are finding their customers increasingly selective concerning the quality of produce that they are willing to purchase ... Consequently, Vincentians

\footnotetext{
${ }^{5}$ The extent to which supermarkets play to this fear has yet to be examined in great depth, but could perhaps be tackled through an analysis of advertising (see, for example, Coulson 2004).
} 
strive to produce blemish-free crops for the local market by using more pesticides." Jungbluth (1997) in Thailand, Dinham (2003: 577) in Vietnam, Medina (1987: 151) in the Philippines, and Rodríguez (1983: 28) in Costa Rica all make similar observations about high pesticide use in vegetables to meet high aesthetic requirements for national market (Figure 2). Thus, like farmers in the North, farmers in the global South must meet strict consumer expectations for produce: they must be blemish-free. ${ }^{6}$

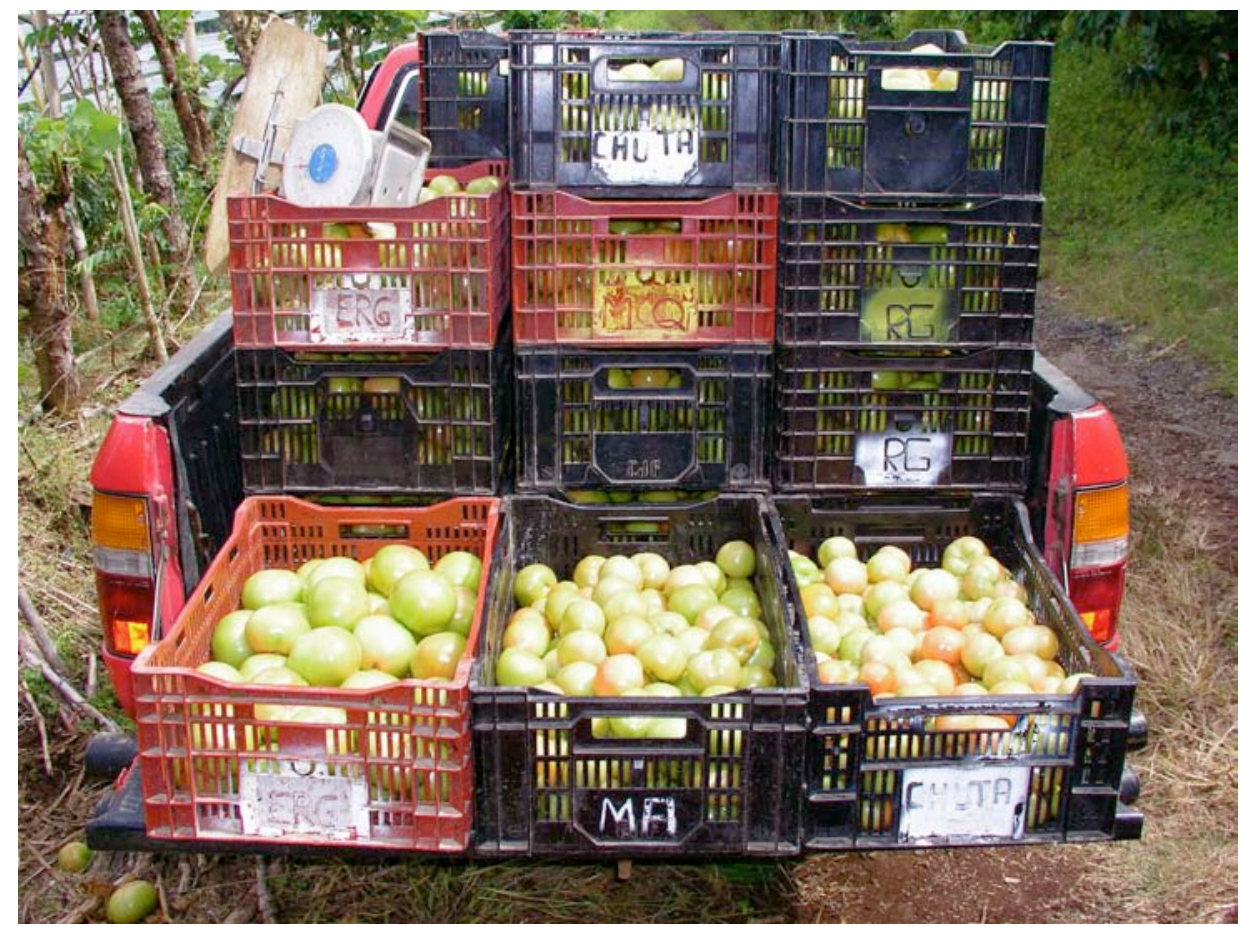

Fig. 2: The three levels of tomato quality for the Costa Rican national market (author). The largest and least blemished (left) fetch the highest prices, while the prices for second and third quality, both smaller and often with more damage, make considerably less. In conventional farming systems, these size and aesthetic standards require heavy applications of fertilizer and frequent pesticide applications.

The brief overview below shows that national market vegetables in developing countries have serious pesticide residue problems, with residues often exceeding maximum residue levels (MRLs, or tolerances) for the country in which they were produced, as well as MRLs of international bodies and industrialized nations. This is especially the case with organophosphates and carbamates, neurotoxic insecticides related to nerve toxin gases developed during World War II (Russell 2001). The organophosphates and carbamates are of particular concern since they have caused documented episodes of consumer pesticide poisoning and are responsible for the majority of overall poisonings, especially among farm workers, in developing countries (Ecobichon 2001; Gupta 2004). In Costa Rica, these two chemical classes caused at least 34.3 percent of all poisonings in 1996 (Leveridge 1998, 43), while they made up 15.4 percent of the volume of imported pesticides (Chaverri 1999: 17).

Residue tests done on a limited basis in developing countries reveal that pesticide residues on fresh produce are widespread and often exceed residue standards. Table 1 shows various results from pesticide residue tests, revealing that most fresh produce has detectable residues and that these very often exceed limits either of the country, the United Nations Food and Agriculture Organization (FAO), or industrialized countries (various reference points are used). Table 1 does not show the level by which standards are exceeded, but it is often quite large. For example, a study of pesticide residues in Quito, Ecuador, showed that the average level of methamidophos in tomato was more than 15 ppm (Hidalgo 1980, cited in Probst et al. 1999: 54), much higher than U.S. Environmental Protection Agency's (EPA) permitted 1 ppm in tomatoes (EPA 2004) and FAO's maximum residue level (MRL) is $0.01 \mathrm{ppm}$ in tree tomato (FAO 2005).

\footnotetext{
${ }^{6}$ Tracing historically the development of this expectation would be a very interesting project, and has not yet been done to my knowledge.
} 


\begin{tabular}{|c|c|c|c|c|c|}
\hline Product & Samples & $\begin{array}{c}\text { \% with } \\
\text { Residues }\end{array}$ & $\%$ Illegal & Place & Source \\
\hline vegetables & 1000 & - & $35 \%(\mathrm{OCs})^{1}$ & Hyderabad market, India & 1 \\
\hline leafy vegetables & 300 & - & $100 \%(\mathrm{BHC})^{2}$ & Mysore, India & 1 \\
\hline horticultural crops & - & - & $40 \%$ & Kenya & 1 \\
\hline vegetables & - & - & $>50 \%$ & Sri Lanka & 2 \\
\hline vegetables & - & - & $>50 \%$ & Togo & 2 \\
\hline vegetables & - & $\begin{array}{l}37 \% \\
(\mathrm{OCs})^{1}\end{array}$ & - & Thailand & 3 \\
\hline cowpea & - & - & $10 \%$ & Thailand & 3 \\
\hline tangerine & - & - & $10 \%$ & Thailand & 3 \\
\hline kale & - & - & $20 \%$ & Thailand & 3 \\
\hline chiles & - & - & $\begin{array}{c}87.5 \% \\
(\text { malathion) }\end{array}$ & Egypt & 4 \\
\hline $\begin{array}{l}\text { cereals, pulses, milk, } \\
\text { eggs, meat and } \\
\text { vegetables }\end{array}$ & - & $53 \%$ & $34 \%$ & Egypt & 4 \\
\hline produce & - & - & $\begin{array}{c}2-5 \% \\
\text { (OCs\&OPs) }^{4}\end{array}$ & farmers' markets, Brazil & 4 \\
\hline produce & - & - & $41 \%$ & $\begin{array}{c}\text { supermarkets, São Paulo, } \\
\text { Brazil }\end{array}$ & 4 \\
\hline produce (11 types) & 一 & - & $80 \%$ & $\begin{array}{c}\text { supermarkets, São Paulo, } \\
\text { Brazil }\end{array}$ & 4 \\
\hline lettuce & 70 & - & $100 \%$ & Nicaragua & 5 \\
\hline cabbage & 140 & - & $71 \%$ & Nicaragua & 5 \\
\hline chilitoma & 85 & - & $65 \%$ & Nicaragua & 5 \\
\hline watermelon & 117 & - & $41 \%$ & Nicaragua & 5 \\
\hline tomato & 200 & - & $27 \%$ & Nicaragua & 5 \\
\hline potato & 25 & - & $8 \%$ & Nicaragua & 5 \\
\hline eggplant & 6 & $100 \%$ & $0 \%$ & Delhi, India & 6 \\
\hline cabbage & 7 & $100 \%$ & $0 \%$ & Delhi, India & 6 \\
\hline tomato & 7 & $100 \%$ & $71 \%$ & Delhi, India & 6 \\
\hline cauliflower & 7 & $100 \%$ & $43 \%$ & Delhi, India & 6 \\
\hline chiles & 5 & $100 \%$ & $20 \%$ & Delhi, India & 6 \\
\hline okra & 7 & $100 \%$ & $29 \%$ & Delhi, India & 6 \\
\hline mustard & 5 & $100 \%$ & $40 \%$ & Delhi, India & 6 \\
\hline
\end{tabular}

Table 1: Pesticide residues on produce in developing countries, various years. Sources: (1) Bull 1982: 57-58; (2) Schwab 1995: 42; (3) Palakool 1995, cited in Jungbluth, 1997; (4) Dinham, 1993: 57, 90, 169; (5) Anonymous 1998: 30; (6) Mukherjee 2003: 270.

${ }^{1}$ OCs are organochlorines, including DDT, endrin, aldrin, etc.

${ }^{2} \mathrm{BHC}$ is an organochlorine insecticide, also known as lindane.

${ }^{3}$ malathion is an organophosphate insecticide.

${ }^{4}$ OPs are organophosphates.

While there is a prominent academic discourse in the North that consumers should not worry about pesticide residues in produce (Ames et al. 1990; Lomborg 2001), there is also a counter discourse arguing that these residues over a lifetime can pose real risks (Baker et al. 2002; Benbrook 2002) or at least should be avoided out of precaution (Pollan 2006: 179). Absent from both of these discourses is available evidence that high residue levels can and sometimes do cause consumer poisonings. In some cases, food-borne pesticide residues kill people, though these cases generally result from inadvertent food contamination and 
not from pesticide applications in agricultural production. ${ }^{7}$ More common are hospitalizations due to food poisoning from pesticide residues, ${ }^{8}$ although there are few registrations of these types of poisonings and they are rarely discovered, let alone reported in the literature (Wu et al. 2001). Reported symptoms of pesticide poisoning from residues on food are nausea, vomiting, chills, sweating, dizziness, abdominal pain, diarrhea, and headache, which — while symptomatic of pesticide poisoning in general — are easily mistaken by consumers and doctors alike for symptoms of other types of food poisoning, especially from bacterial pathogens (Green et al. 1987). The problem is that only with "careful clinical and epidemiological investigation" can the origins of food poisoning outbreaks due to pesticides be identified (Wu et al. 2001: 333-4).

The recent documented cases in the medical literature come from Malaysia, Taiwan, and Hong Kong. Methamidophos - a very acutely toxic, systemic organophosphate insecticide — was the culprit in all cases. In September 1991, eleven people in Malaysia were hospitalized due to food poisoning from methamidophos residues on the leafy green vegetable sayur manis, which had methamidophos residue levels 500 times above the permitted level (Dinham 1993: 179). In investigating the four pesticide residue poisoning cases in Taiwan reported by Wu et al. (2001: 335), researchers found leftover vegetables contained extremely high levels of methamidophos: $225 \mathrm{ppm}^{9}$ in sweet potato, $110 \mathrm{ppm}$ in the leafy green Gynura bicolor, and $26.3 \mathrm{ppm}$ in red cabbage. For a reference point, the U.S. MRL for methamidophos ranges from 0.1 to $1 \mathrm{ppm}$ (EPA 2004: 404). Taiwan banned the use of methamidophos on most vegetables in 1994, but $\mathrm{Wu}$ et al. (2001: 336) report that "because it is cheap and highly potent, the illegal use of methamidophos is still common among farmers."

Vegetable-borne methamidophos poisonings were once common in Hong Kong, where physicians began watching for it specifically. Figure 3 shows that in 1988, Hong Kong experienced 312 documented outbreaks of consumer poisonings from methamidophos residues. Hong Kong was able to decrease the frequency of these types of poisonings by banning methamidophos in 1988 and by spot-testing imported produce for residues before it entered the country (Chan 2001). While the Hong Kong case is encouraging and suggests useful corrective measures, it is likely more common that poisonings from consumption of high levels of pesticide residues are not diagnosed and not recorded as such in most countries, but instead pass as bacterial food poisoning.

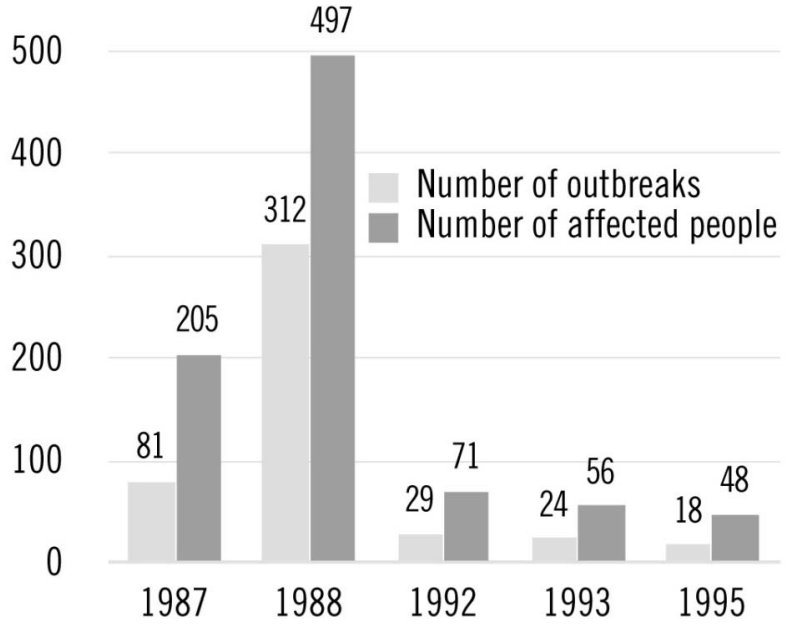

Fig. 3: Vegetable-borne methamidophos poisonings in Hong Kong. Source: Chan 2001: 337, Table 1 .

Other cases of acute illness linked to pesticide residues exist, but are not in the medical literature. Dinham (1993: 34) reports that in Egypt, cases of gastrointestinal illnesses such as diarrhea have been attributed to pesticide contaminated fruit and vegetables for decades. This accompanied the rise of vegetable cultivation in plastic houses and tunnels, which results in "heavy residues from frequent applications of

\footnotetext{
${ }^{7}$ Shortly after the introduction of pesticides in India, 100 people died in Kerala after eating parathion-contaminated wheat flour (Gupta 2004: 85). Many other such deaths have been reported in other countries (Dinham 1993: 55). Historically there were cases of children in the U.S. being killed by lead arsenate residues on produce (Whorton 1974). It is conceivable that lead arsenate still causes such problems where it is used but that these go undocumented.

${ }^{8}$ Poisoning outbreaks from pesticide residues have also happened in the U.S. recently (Farley and McFarland 1999; Green et al. 1987) and historically (Whorton 1974).

${ }^{9}$ Parts per million, equivalent to $\mathrm{mg} / \mathrm{kg}$.
} 
pesticides, without observing the safe interval between the final spray and harvesting" (Dinham 1993: 56). The culprit insecticides in Egypt are mostly organophosphates and carbamates: dimethoate, methamidophos, methomyl, and monocrotophos. Sudan also has had residues cause pesticide poisonings. In the 1990-1991 cotton season, 45 pesticide poisoning cases were admitted to hospitals in the cotton growing provinces of Gezira and Blue Nile. Surprisingly, 25 cases were caused by eating pesticide-contaminated vegetables or wheat (Dinham 1993: 46-7). In Paraguay, there is concern about the increasing numbers of pesticide poisonings from consumers eating above-ground produce like cabbage, lettuce, and tomatoes (Dinham 1993: 128).

These incidents and other limited evidence suggest that the burden of residues in developing countries is considerably higher than in industrialized countries, and has real consequences. A report from India shows that 51 percent of all food commodities had pesticide residues, and that the MRL was exceeded in 20 percent, whereas these figures worldwide are 20 percent for contamination and 2 percent in excess of the MRL (Agnihorti 1999, cited in Gupta 2004). Another Indian study showed that "all food commodities contain pesticide residues, and the average intake through food was estimated at $223 \mu \mathrm{g}$ per person per day, compared with $3.8 \mu \mathrm{g}$ in the USA" (Dinham 2003: 578). Another study estimated that the average daily intake of $\mathrm{HCH}$ and DDT in India was 115 and $48 \mu \mathrm{g} /$ person, respectively, which is much greater than intake in industrialized nations (Kannan et al. 1992). As one would expect, very high levels of pesticides are found in Indian samples of human milk, fat, and blood (Bhatnagar 2001, cited in Gupta 2004). Links between pesticide residues and other negative health effects of pesticides - immune system suppression, nervous system damage, cancer, and birth defects - have not been explored, and it would take enormous effort and twenty years or more for epidemiological studies to adequately address the question (Cohen 1987: 48, cited in Culliney et al. 1993: 143).

Shifting our focus to Costa Rica, a number of pesticide residue studies show that the rate at which Costa Rican national market produce violates residue standards is quite high, from nine to 30 percent (García 1997; Rodríguez Solano 1994; Valverde Gómez et al. 2001). These rates are substantially higher than the violation rate of Costa Rican produce imported into the U.S. - 4.4 percent for all Costa Rican fresh vegetables imported from 1996 to 2006 - and also of U.S. domestic produce consumed in the U.S., which was 1.6 percent from 1996 to $2006 .{ }^{10}$ While caution is advised in interpreting these rates due to difference in sampling and residue analyses conducted, violation rates due to illegal or excessive residues appear to be far greater in Costa Rican produce for national market than for exported produce and for domestic produce in the North. The section below examines the specific market segments that exist in Costa Rica and the different strengths of pesticide residue regulation within them.

\section{Markets and pesticide residue control in Costa Rica}

Three market channels are relevant to pesticide residues in Costa Rica: the open domestic market, the controlled domestic market, and the export market. The open national market consists of farmers selling their produce to intermediaries or directly to consumers at ferias (farmers' markets). The intermediaries sell to retailers like supermarkets and produce stands and to various businesses that supply the Costa Rican food industry. These food industry businesses are mostly small, with 93 percent having fewer than 99 employees (Kopper 2002: 2). The vast majority of these companies have not adopted food safety standards because of their cost and because most consumers "are not aware of their right to safe foods and are mainly interested in purchasing items at the lowest possible price" (Kopper 2002: 2). A recent study found that 59 percent of Costa Rican food industries had no raw material specifications (Kopper 2002: 3), so for national market intermediaries and farmers supplying them there is little pressure to comply with pesticide residue standards. ${ }^{11}$ Valverde et al. (2001: 82) note, "the intermediaries that provide the produce markets and the roving truck farmer are not held accountable directly if contamination is detected in their products." ${ }^{12}$ Similarly, ferias place no demands upon farmers in terms of monitoring pesticide residues. Like in most developing countries, the majority of produce in the Costa Rican national market faces minimally enforced demands to comply with Costa Rican pesticide residue standards. There are some efforts, however, to control pesticide residues in the Costa Rican market with the Sello Azul, or Blue Seal, program.

The controlled national market refers to produce covered by the Blue Seal program, a Costa Rican agro-food standard. Costa Rica's Blue Seal program is run by supermarkets and the Sanidad Vegetal department of the Ministerio de Agricultura y Ganadería and has the goal of certifying produce that complies with Costa Rican pesticide MRLs (Kopper 2002). It is voluntary and is designed mostly for supermarkets or large intermediaries that supply supermarkets, reflecting a broader trend toward private standard regulation in agro-food systems (Le Heron and Roche 1999; Marsden et al. 1999; Murdoch et al. 2000). To receive the seal the company must comply with the standards for six months and must regularly supply a determined

\footnotetext{
${ }^{10}$ Percentages are from unpublished analysis of data from the Food and Drug Administration.

${ }^{11}$ Food safety issues in Costa Rica extend far beyond a lack of control over farmers' pesticide use. Of the food industry businesses surveyed, 63 percent have "no structured sanitation or cleaning program," 78 percent "have no hand cleaning facilities for employees," and 67 percent "do not control or treat water used for processing" (Kopper 2002: 3).

${ }^{12}$ All translations from Spanish to English are made by the author.
} 
number of samples for laboratory analysis. These samples should include the name and address of the farmer so that MAG can advise them on proper pesticide use (Castillo Nieto 1999). ${ }^{13}$ Business certified under Blue Seal can label their produce with a sticker saying "Business with control of pesticide residues" (Castillo Nieto 1999: 17).

The first company to receive the Blue Seal was Hortifruti División Vegetales, owned by Corporación de Compañías Agroindustriales de la Corporación de Supermercados Unidos (Grupo Más por Menos). As part of this program, Hortifruti "invests resources in random tests with the goal of detecting agricultural contamination among [the produce of] its providers" (Valverde Gómez et al. 2001: 82). Hortifruti is by far the largest fresh fruit and vegetable supplier in Costa Rica. It has informal contracts with farmers and acts very similarly to exporters, relying "on careful selection of growers and then the maintenance of a stable relationship" and providing farmers with "stable access to an attractive and growing market, at prices that are close to but usually a bit above the wholesale market, plus technical assistance, and for the small farmers, input credit" (Berdegué et al. 2005: 265). Hortifruti also conducts pesticide residue tests through Sanidad Vegetal's lab, which cost $\$ 200$ for the farmer (Berdegué et al. 2005: 266). If violations are found in "either the pesticide or $E$. coli fronts, this is used to orient the technical assistance and training activities of their field staff rather than to signal delisting of the supplier" (Berdegué et al. 2005: 266). ${ }^{14}$

While the Blue Seal signals greater control over pesticide residues in vegetables, it appears that its current implementation allows for skirting of monitoring since companies can choose the produce to submit, and the Blue Seal program does not contact every farmer involved. Viewed skeptically, the Blue Seal program is a way of differentiating produce sold in supermarkets from those sold in farmers' markets, implying that it has fewer or lower pesticide residues and is of higher quality, the nebulous but powerful concept that is also becoming important for Costa Rican consumers (Berdegué et al. 2005). Valverde et al.'s (2001) residue study points to the problems with this view since pesticide residues examined were present with equal frequency in produce sold at farmers' markets and supermarkets. ${ }^{15}$

The export market places the greatest demands on farmers to comply with pesticide residue standards. U.S., Canadian, and European regulatory agencies spot test produce for pesticide residues. While only one percent or less of produce is tested, the six main exporters in Northern Cartago and the Ujarrás Valley all take pesticide residue violations seriously since the cost of violations is the loss of a shipment worth $\$ 10,000$ or more (Galt 2007). They have experienced violations in the past, and now each communicates requirements with their contract farmers, and most use policing mechanisms to exert control over pesticide use (cf. Wolf et al. 2001). Exporters generally proscribe organochlorine and organophosphate pesticides and suggest use of pyrethroids and biopesticides in their stead.

While lax compared to its export markets, Costa Rica's public regulatory framework for pesticides has improved recently, but monitoring and enforcement in the open national market are still minimal. As of 1990, Costa Rica had established pesticide tolerances for only 25 pesticides on strawberries and seven on dried cacao (García 1990). In 1997, a large number of tolerances were established in the official government register, La Gaceta (1997). Costa Rican law dictates that the foods in the standard market basket be tested for pesticide residues. Sanidad Vegetal is responsible for conducting residues tests on national market produce with its laboratory, which began monitoring in 1991 (Castillo Nieto 1999: 17). This was spurred in part by investigative reporting that highlighted extremely lax enforcement and widespread pesticide misuse, especially in vegetables (Barquero S. 1990; Barquero S. and Navarro 1990a, 1990b; Navarro and Barquero 1990).

In 1999, the lab was conducting 50 tests per week for national market, imported goods, and exports. Each residue test for the Sanidad Vegetal of MAG cost 45,000 colones, equivalent to $\$ 158$ at the time. Some exporters "turn to this service to present proof of health [innocuousness] to those countries where they send their products" (Barquero S. 1999: 25A). Although this testing exists, these residue tests for national market produce have little impact on the open national market channels. The vast majority of farmers and produce

\footnotetext{
${ }^{13}$ The implication is that the samples are not randomly and independently chosen, which could mean that sellers are able to provide produce from their most trusted farmers.

14 Farmers' views of Hortifruti's control over pesticides are divided. For one, some farmers believe that Hortifruti randomly tests for residues, while others were adamant that farmers had to bear the costs of residue testing if they wanted it done. Others reported that Hortifruti exercised no control over their pesticide use, only caring about the amount and appearance, and charging for pesticide residue tests. The manager of one vegetable exporting business, which has participated in Blue Seal, is skeptical of its efficacy and implementation so far: "Basically, there's no follow through on it. For example, Hortifruti has tons and tons of different producers and they have the Blue Seal, but nobody does the registro (agrochemical logbook). So it doesn't mean anything" (Interview, April 9, 2003).

${ }^{15}$ They found that both marketplaces had residues above tolerances at a similar rate for sweet chile, leading them to conclude that marketplace makes no difference for pesticide residues. For fecal coliform contamination, however, they found that supermarkets tend to have lower levels of contamination, though "both sites appear to have fecal contamination problems with their products" (Valverde Gómez et al. 2001: 65). Fecal contamination became a national concern after a television news program showed that lettuce grown near the city of Cartago was irrigated with water from drainage systems that receive untreated sewage.
} 
buyers I surveyed and interviewed were unaware of sanctions against farmers who sold produce with high levels of residues on the Costa Rican market. Farmers almost universally agreed that they have complete freedom of pesticide use when selling on the open national market. Thus, there is a regulatory framework on which to base monitoring and enforcement, yet both of these are relatively lax, likely because of two decades of structural adjustment and continued high foreign debt levels which have sapped budgets for government programs generally.

\section{Study site and methods}

The data on pesticide use on national market vegetables come from a survey of 148 farmers and indepth, semi-structured farmer interviews I conducted between late April 2003 and early January 2004 in Northern Cartago and the Ujarrás Valley, Costa Rica. In this area, which is Costa Rica's premier vegetable growing region, truck farmers cultivate fertile volcanic and alluvial soils to produce more than 30 types of vegetables for national and export markets. Squash, green bean, and chayote produced for the open national market are focus crops for the analysis below since we can compare pesticide use on them to the same crops grown for export. ${ }^{16}$

National market production remains extremely important in Northern Cartago and the Ujarrás Valley. Costa Rican agricultural census data provide information on chayote and potato, but not on the other vegetable crops in the area. ${ }^{17}$ In the Ujarrás Valley, about half of the 555 hectares in chayote are devoted to export, while the remaining half provision the national market (SEPSA, 2004: 51). More than 3,000 hectares in Northern Cartago produce potato for national market, and it is likely that the amount of land in other important national market crops like carrot, cabbage, and onion locally is in the many hundreds of hectares for each crop.

Some comments on survey design are necessary. The first relates to obtaining data on pre-harvest interval (PHI), which is the amount of time that passes between spraying and the next harvest. In my first few surveys I found that farmers rarely voluntarily say they leave only a few days between spraying and harvesting if I asked, "How many days are there between the last spray and the harvest?" When phrased this way, farmers often answered between one to four weeks, even for consecutively harvested crops for which this would be impossible (many vegetables, including sweet pepper, chayote, squash, and tomato, produce fruit consistently in their harvest stage, with harvests every two to four days for several months). In contrast, I found answers that better corresponded to common practices in the area like weekly spraying when I asked in regard to these continuously harvested crops, "When during the week do you harvest?" The response was along the lines of "Every Monday, Wednesday, and Friday," which allowed me to follow up with, "So when do you spray?" When phrased this way, farmers responded with answers like "Every Monday after harvest" or "On Saturdays." I interpret this to mean that farmers do not want to be seen as spraying close to harvest since it could be seen as a lack of consideration for consumer well-being, even though most find it a necessary practice to maintain their harvest.

Acquiring data on the pesticide dose used requires a series of questions. To calculate pesticide dose by pesticide in kilograms of active ingredient ${ }^{18}$ (ai) per hectare, I (1) asked farmers the number of estañones (50 gallon drums) of spraying mixture they used per unit of land, (2) asked farmers the quantity of each specific pesticide they use per estañón, (3) photographed the label of each pesticide for information on the percentage of active ingredient, and (4) determined the measured quantity of each pesticide container sold in the area, e.g., 900 grams in a package. Together, the first three allow me to calculate the amount of active ingredient used per unit of land, from individual pesticides to all pesticides used during a crop cycle. The last piece of information corrects farmers' tendency to round to the nearest whole unit (e.g., saying a kilogram for 900 grams). Farmers provided the first two sources of information while agrochemical sales places provided the last two. In addition to many other questions, the survey also involved a set of questions on determining the produce buyers and ultimate markets to which produce is sent. Below I use data from my farmer surveys and in-depth, semi-structured interviews with farmers to discuss issues of pesticide type, dose, and PHI and to compare national market farmers' pesticide use to that of export farmers.

\footnotetext{
${ }^{16}$ For reasons of brevity I exclude data on dozens of other vegetable crops such as peppers, tomatoes, and potatoes. For more detail on the specific crops in examined here, see my other work (Galt 2008).

${ }^{17}$ As Horst (1987) notes, vegetable production systems are extremely complex, often eluding the simple categorizations of census surveys.

${ }^{18}$ Commercial pesticides are made up of active ingredients and other ingredients, which together make up the formulated product. Active ingredient refers to the compound that kills, mitigates, or repels the pest organism. The rest of the formulated pesticide is composed of other ingredients, which often increase the efficacy or spread of the active ingredient.
} 


\section{Results}

\section{The logic of using residual and highly toxic insecticides}

In terms of residues on food, an important choice conventional vegetable farmers make is choosing between the less residual insecticides (like pyrethroids and biopesticides) and the generally more persistent and acutely toxic organophosphates and carbamates. During the course of fieldwork, I came to understand that without regulation, farmers would tend to choose the organophosphates because they are more effective per monetary unit spent. Table 2 shows the average agrochemical cost (not including labor and other costs) of an insecticide application in the study site by chemical class and active ingredient. While not immediately apparent that organophosphates are the most effective insecticides per monetary unit, one must consider how persistent the insecticide is on and in the plant. High PHIs generally indicate pesticides that break down slowly, while low PHIs suggest fast-degrading products.

\begin{tabular}{|c|c|c|c|c|}
\hline $\begin{array}{l}\text { Chemical class / active } \\
\text { ingredient }\end{array}$ & $\begin{array}{l}\text { Toxicity } \\
\text { class }\end{array}$ & $\begin{array}{c}\text { Oral LD }_{50} \\
(\mathrm{mg} / \mathrm{kg})\end{array}$ & $\begin{array}{c}\text { Average cost/ha } \\
(\text { US \$) })^{1}\end{array}$ & PHI \\
\hline \multicolumn{5}{|l|}{ Organophosphates (OPs) } \\
\hline chlorpyrifos & II & $135-163$ & $\$ 7.47$ & 20 \\
\hline diazinon & II & $300-400$ & $\$ 13.08$ & 10 \\
\hline dimethoate & II & $290-325$ & $\$ 9.44$ & $14-21$ \\
\hline \multirow[t]{2}{*}{ methamidophos } & $\mathrm{Ib}$ & 20 & $\$ 8.53$ & $10-21$ \\
\hline & Average: & 465.3 & $\$ 9.63$ & 15.75 \\
\hline \multicolumn{5}{|l|}{ Organochlorines (OCs) } \\
\hline \multirow[t]{2}{*}{ endosulfan } & II & 70 & $\$ 10.93$ & 2 \\
\hline & Average: & 70 & $\$ 10.93$ & 2 \\
\hline \multicolumn{5}{|l|}{ Pyrethroids (Ps) } \\
\hline cyfluthrin & II & $869-1271$ & $\$ 13.33$ & 14 \\
\hline cypermethrin & II & 247 & $\$ 5.19$ & $0-15$ \\
\hline deltamethrin & IV & $128-5000$ & $\$ 12.85$ & 8 \\
\hline \multirow{3}{*}{$\begin{array}{l}\text { lambda-cyhalothrin } \\
\text { permethrin }\end{array}$} & II & $56-79$ & $\$ 6.98$ & 1 \\
\hline & II, IV & 4000 & $\$ 10.41$ & 0 \\
\hline & Average: & 1343.1 & $\$ 9.75$ & 5.08 \\
\hline \multicolumn{5}{|c|}{ Synthetic insecticides with new modes of action (NI) } \\
\hline imidacloprid & III & 450 & $\$ 57.94$ & 21 \\
\hline teflubenzuron & IV & $>5000$ & $\$ 13.84$ & 15 \\
\hline \multirow[t]{2}{*}{ thiamethoxam } & IV & 1563 & $\$ 22.47$ & 3 \\
\hline & Average: & 2337.7 & $\$ 31.41$ & 13 \\
\hline \multicolumn{5}{|c|}{ Botanical, microbial, \& organic insecticides $(\mathrm{B} / \mathrm{M} / \mathrm{O})$} \\
\hline avermectin & II & 10 & $\$ 98.91$ & 0 \\
\hline \multirow{4}{*}{$\begin{array}{l}\text { Bacillus thuringiensis } \\
\text { potassium salt, oleic acid } \\
\text { spinosad }\end{array}$} & IV & $>5000$ & $\$ 23.18$ & 0 \\
\hline & IV & $>5000$ & $\$ 23.55$ & 0 \\
\hline & IV & 3738 & $\$ 37.27$ & 3 \\
\hline & Average: & 3437 & $\$ 45.73$ & \\
\hline
\end{tabular}

Table 2: Cost of insecticides per hectare, Northern Cartago, July 2003. Sources: IRET 1999; pesticide labels; and analysis of General Inventory Report from Insumos Agropecuarios ADICO, Cipreses, Cartago Province, Costa Rica, July 28, 2003.

${ }^{1}$ Averages were calculating by determining the cost per hectare of each formulation and package size of the pesticide available at the store, for both the minimum and maximum dose recommended on the label. A 2003 exchange rate of CR $₫ 395 / \mathrm{US} \$ 1$ was used.

The problem with the pyrethroids from a production standpoint is that most degrade to below effective levels in a few days, leaving the plants unprotected from insects. This is their benefit to the consumer and the farmer seeking to avoid residues: they leave very low levels of residues after only a few days, most often below the limits of detection of commonly used residue analysis equipment.

In contrast, many organophosphates, especially the systemic ones like methamidophos, have much 
longer half-lives and persist at high enough levels to kill insects often for weeks after application. Some export farmers explained to me the tradeoff of having to spray the synthetic pyrethroids more frequently than the organophosphates to achieve the same level of control. José, when asked if export requirements for low residues affected his production practices, responded: "The only thing it does is you have to apply a little more, shorten the cycle of applications. Let's say, if I spray with residual pesticides [organophosphates] every 8 days, with the non-residuals [pyrethroids] I have to spray every 5 days" (Survey, September 25, 2003). In another conversation with a farmer who used to produce entirely for the national market and had switched to the export market, I was trying to understand what many farmers and exporters communicated as the continuing temptation to use methamidophos as opposed to the less residual and newer pyrethroids. We stood in his green bean field under an unused chayote trellis:

$R G$ : Is it because methamidophos is cheaper?

Rodrigo: It is not cheap, but rather the effect on the plant lasts longer than the products I use, the pyrethroids. ${ }^{19}$ The pyrethroids, they have a shorter duration on the plant. Meanwhile, methamidophos, if you apply methamidophos, you know the plant is protected for 15,22 days.

$R G$ : And in chayote there are still people who use methamidophos?

Rodrigo: Yes. It is prohibited. It is prohibited, but people spray it on. People spray it because in chayote it is the product that one [traditionally] uses. For example, cypermethrin [a synthetic pyrethroid], in chayote, cypermethrin doesn't do a thing for you.

$R G$ : So what do you use in chayote? Do you have to use methamidophos still?

Rodrigo: No, because I use a higher dose of cypermethrin.

$R G$ : Does it work like that?

Rodrigo: It works like that. But you have to spray it more frequently.

$R G$ : So it costs a little more.

Rodrigo: It costs a little more.

$R G$ : And if you didn't have a fixed price [as a result of the policy of two exporters in the area], you would always be trying to have the lowest costs.

Rodrigo: That's right (Interview, December 10, 2003).

There are a few other references to this connection in the literature. Opondo (2000: 38), writing on French beans produced in Kenya for export to Europe, notes that

[t]he high cost of environmentally sound agrochemicals ${ }^{20}$ causes a lot of farmers to avoid using some of those recommended, and to continue to use proscribed chemicals. But this can only be in the short term because testing for the maximum residue regulation has already begun in Europe, and produce not found adhering to this regulation will be rejected.

Arbona (1998) also makes this connection, though at the national level. As the export farmer above describes, it is not just price, but price relative to how well the agrochemicals work and how long it remains effective in the field.

This logic helps explain why many studies find that national market farmers tend to use more residual pesticides, especially organophosphates and methamidophos, that can leave high levels of residues that cause consumer poisonings (e.g., Abeysekera 1988; Yen et al. 1999). Alone, however, this does not adequately explain high residues on national market produce, since farmers could apply these pesticides and wait until they dissipate before harvest. High levels result from not waiting long enough, i.e., not respecting the PHI. Why is PHI often not respected?

To answer this, we must consider other facets of vegetable production and markets, one biological and the other economic: frequency of harvest and variability of prices that farmers receive. Many vegetable crops by their biological nature are consecutively harvested every few days or every week for weeks or months on end. These include botanical fruits used as vegetables, such as chayote, cucumber, eggplant, green beans, peas, peppers, squash, and tomato. Once these are in harvest, the maximum time a farmer can

\footnotetext{
${ }^{19}$ Like almost all farmers in the study site, Rodrigo refers to the synthetic pyrethroids (cypermethrin, permethrin, etc.) as piretrinas, which translates to pyrethrins. Pyrethrins are part of the botanical insecticide pyrethrum, taken from chrysanthemum flowers. Since he means pyrethroids, I have translated as such. This confusion also exists in the literature, where some authors inadvertently state that organic pesticides include or contain pyrethroids (e.g., FernandezCornejo et al. 1998).

${ }^{20}$ Assumedly Opondo means the pyrethroids, which are perhaps less environmentally damaging than other types of insecticides since they break down faster. It is important to note that they still can impact fish and wildlife before they decompose and have negative human health effects.
} 
wait between a spray and a harvest is the period between harvests, which ranges from a few days to a week, depending on the crop and variety. Thus, when organophosphates are used during this consecutive harvest period, high levels of residues will often result, especially during the first few harvests after the spray.

Residue decline studies show what happens to methamidophos residue levels depending on the number of applications and the PHI. Figures 4 and 5 show residue decline studies conducted on cucumbers grown in greenhouses in Spain. The data in Figure 4 show the residues in cucumbers after only one application of methamidophos. After just one application, it takes almost three weeks for residues to drop below $0.1 \mathrm{ppm}$, the level that is detected by most residue tests.

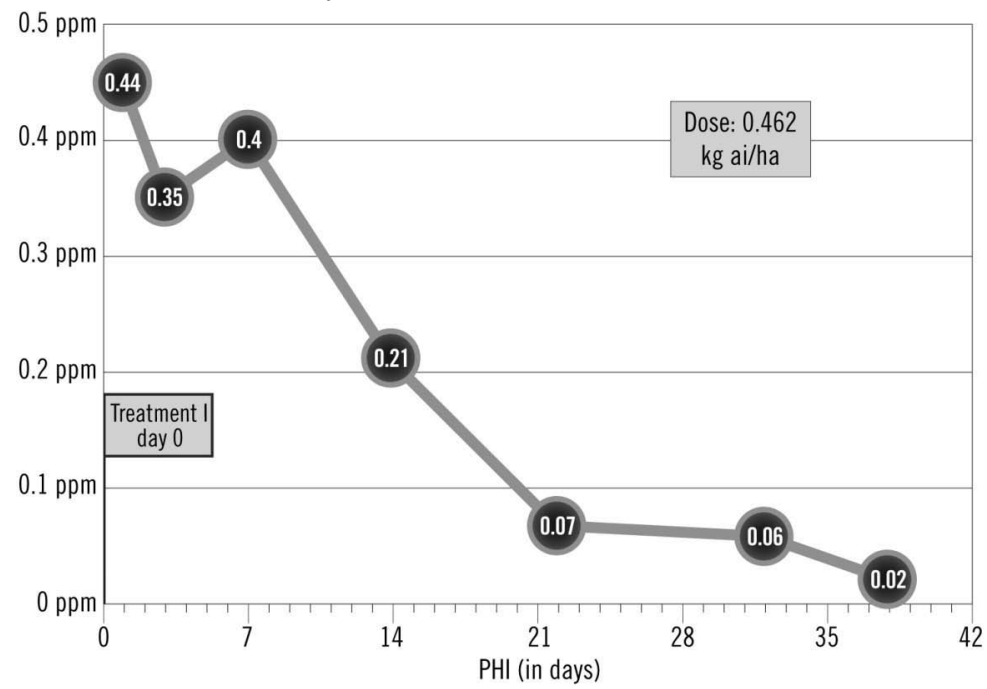

Fig. 4: Levels of methamidophos residue in cucumber following one application. Source: Aguilar-del Real et al. 1999: 3356, Table 2.

The regular use of methamidophos causes residues to accumulate in the plant since it is a systemic insecticide that takes several weeks to break down. Figure 5 shows this to be the case in cucumbers (note the difference in scale from Figure 4 on both the $x$ - and y-axes). The frequency of application in Figure 5 is once every two weeks. By the fifth application, considerable residues have built up in the cucumbers over the course of the production cycle. Tests on pepper and tomato display the same pattern (Aguilar-del Real et al. 1999). Concerning the final levels of methamidophos, the authors of the residue decline study note that "these data seem to indicate the existence of a certain long-term accumulative effect for this pesticide. These results are in agreement with the high residue levels of methamidophos sometimes found by regulatory agencies in residue monitoring" (Aguilar-del Real et al. 1999: 3357-8). ${ }^{21}$

Price variability also contributes to the problem of high levels of residues in consecutively harvested vegetables, and can also lead to residue problems in vegetables that are harvested once or twice at the end of the production cycle, like broccoli, cabbage, celery, lettuce, and sweet corn. National market vegetable prices fluctuate strongly at annual, weekly, and even daily intervals. Edelman (1999: 94) describes the Costa Rican national market prices for vegetables as "chaotic." "Prices for onions and potatoes, the Cartago agriculturalists' principle crops, unlike those for coffee and basic grains, were [and continue to be] highly unstable" (Edelman 1999: 96). In the interview with Rodrigo noted above, he explained the effects of this on production strategy: with national market vegetables you have to always keep input costs as low as possible, since "you're gambling with the price on the market." This often means preference for organophosphates to keep total agrochemical costs lower. The connection to residues, farmers explained to me, is that near harvest time a rapid increase in price can mean that less conscientious farmers, or those in a cost/price squeeze who have recently sprayed, will harvest to take advantage of the price. The recently sprayed produce, likely with high levels of residues, will be consumed in the next day or two. Some farmers in the area refuse to eat cabbage because they say the pesticide use practices of their neighbors result in very high levels of residues.

From this discussion we can identify a triad of causes behind the organophosphate and carbamate residue problems on vegetables: (1) higher efficacy per unit price, together with (2) the biological

\footnotetext{
${ }^{21}$ A Costa Rican study of methamidophos residues in lettuce and tomato also found very high residue levels. Lettuce sprayed with six applications of methamidophos every two to three weeks and harvested with a 1-day PHI and a 3-day PHI had residues of $12.79 \mathrm{ppm}$ and $9.74 \mathrm{ppm}$, respectively (Carazo et al. 1984: 943). Tomatoes harvested eight days after the last application had residues of $4.92 \mathrm{ppm}$ (Carazo et al. 1984: 942). EPA tolerance for both of these crops is 1 ppm (EPA 2007).
} 
characteristic of consecutively harvested vegetables and (3) rapid price fluctuations in vegetable markets. Together these mean that in markets with little regulation, farmers will generally prefer the organophosphates, and harvests will often occur without enough time passing between the spray and harvest. This, I argue, is the reason behind the high levels of residues often found in developing countries. Contrary to the majority of the literature, it has very little to do with farmer ignorance, and much more to do with the intersection of farm households' survival in capitalist markets and the ecological aspects of vegetable production including crop biology and susceptibility to pests.

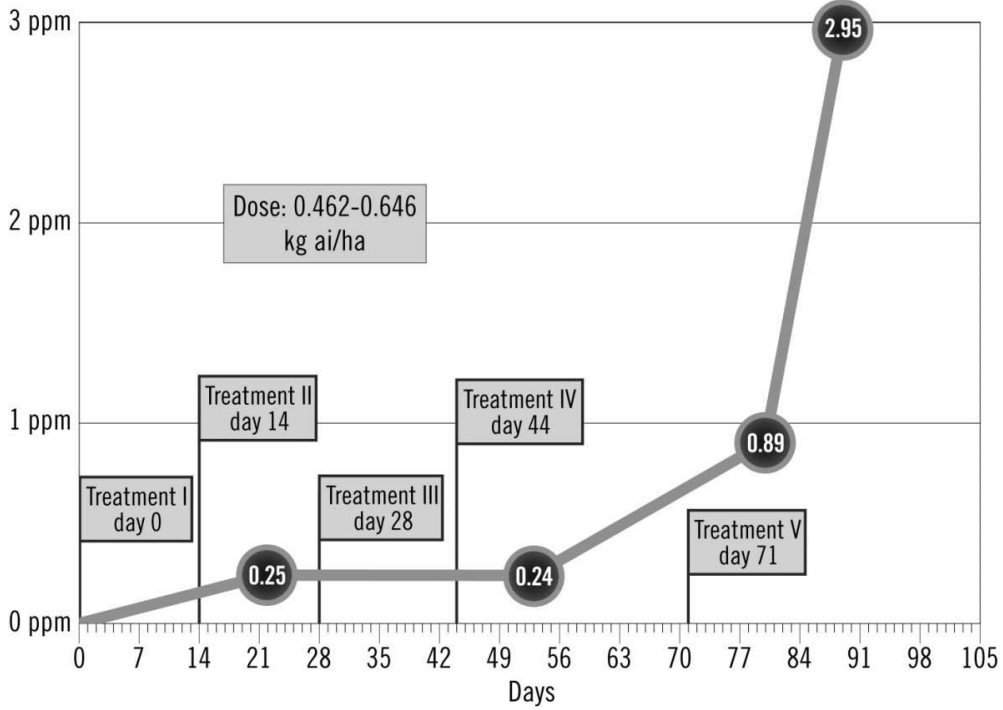

Fig 5: Levels of methamidophos residue in cucumber during and following five consecutive applications. Source: Aguilar-del Real et al. 1999: 3356 \& 3358, Tables 1\&6.

\section{Pesticide use by market segment}

To what extent does this logic differ in pesticide use between farmers in different market segments? In other words, what are the effects of different levels of pesticide residue regulation on farmers' pesticide use as it relates to residues? During the open-ended section of the farmer survey, I asked farmers about the requirements of the national market and the export market. The pattern of observations followed closely along the lines of the first few farmers in the survey. Carlos, a smallholder who sells his produce in farmers' markets, observed, "If you sell to the national market, in reality no one says to you, 'Look, I'm going to do a residue test.' Here the agricultural market is open, no one is put to work to see if residues are high, or anything else, no" (April 23, 2003). Other farmers noted that laws existed, but were not strongly enforced. Juan, who produces vegetables for export and had previously been oriented only to the national market, noted about the national market, "Well, there are requirements, but they are not put into practice. The national market, MAG has a person working in Sanidad Vegetal. They do tests, but they are not very effective, because they do them very sporadically" (May 4, 2003).

This contrasts with export farmers' views of export market requirements. Juan noted the requirements concerning high aesthetic standards and residues:

good formation of the product so that they are sent perfect, almost ... . And all free of residues, free of residues. This is one of the most restrictive limitations they have ... . This clearly has a large cost for us, and [is done] as carefully as possible. I always want to learn much more to use products that are less toxic everyday, and, if it is possible, nothing (May 4, 2003).

While not all export farmers share his thoughts on stopping synthetic pesticide use, his views of residue requirements in the export market are typical. These requirements are viewed as very stringent. Farmers' understandings of these market requirements are strongly shaped by the information provided by the exporters with whom they contract. My interviews with managers of export firms in the area revealed that all proscribe the more residual organophosphate and organochlorine insecticides, although recommendations differ on fungicides (Galt 2006: 140-177).

With these different levels of residue enforcement between the open national market and the export market, we would expect differences in the use of the more residual and highly toxic organophosphate and carbamate insecticides between farmers growing for the different markets, and perhaps in other pesticide classes as well. Table 3 compares groups of pesticides used on three crops - chayote, green bean, and squash — produced for different markets. The statistical tests compare only pesticide use on export and the 
open domestic market since the sample sizes for the controlled national market are too small for statistical inference.

Pesticide use for the different markets shares a number of features. First, pyrethroids are the insecticide group with the highest levels of use across all crops and markets, followed generally by the organophosphates and carbamates. Second, the dithiocarbamates, e.g., mancozeb, are an important fungicide group on all crops. Third, the substituted benzenes, namely chlorothalonil, and inorganic fungicides like sulfur and copper are the other important fungicide groups.

Table 3 also reveals significant differences in insecticide use between the open domestic market and the export market. First, production for the open national market relies on more heavily on organophosphate and carbamate insecticides. This difference is significant across all three crops. Second, for green bean and squash, open national market farmers rely significantly less on purchased botanical, microbial, and organic insecticides - including avermectin, Bacillus thuringiensis, and spinosad - than export-oriented farmers. Third, domestic squash and green bean farmers who sell to the open national market rely significantly more on the older and more persistent organochlorine insecticides than export farmers of the same crop. Fourth, squash and chayote farmers selling to the open domestic market rely significantly less (at the 10 percent level) on newer insecticides with new modes of action (Nauen and Bretschneider 2002) than do export squash and chayote farmers.

There are also some differences in fungicide use between the markets. First, green bean export farmers rely more on botanical fungicides than national market green bean farmers. Second, there are many differences in fungicide use between squash production for different markets. National market squash farmers rely significantly more on dithiocarbamates and inorganics, while export squash farmers use more of antibiotics, botanicals, and other types of synthetic fungicides.

The sample sizes shown in Table 3 of farmers producing for the controlled domestic market are too small to draw strong conclusions, but the table suggests that their insecticide use is closer to export farmers than open national market farmers. As with export crops, pyrethroids are emphasized over the use of organophosphates. This is reinforced by the fact that some of these marketing arrangements were made with farmers already producing for export.

Table 4 shows the use of "Bad Actor" pesticides by market segment for chayote, green beans, and squash. The Pesticide Action Network, an activist and research organization, created the Bad Actor classification to differentiate between pesticides known to cause problems and those that are likely to be less harmful (Kegley et al. 2000). A pesticide qualifies as a Bad Actor if it is any of the following: acutely toxic according to the World Health Organization (WHO), EPA, or the U.S. National Toxicology Program; a known or probable carcinogen according to EPA; a reproductive or developmental toxin listed in California's Proposition 65 list; a cholinesterase inhibitor according to the Material Safety Data Sheet (MSDS), the California Department of Pesticide Regulation, or the PAN staff's evaluation of chemical structure; or a known groundwater contaminant (Orme and Kegley 2004). Despite its creation by an activist organization, the Bad Actor category is relatively conservative. Not included are suspected endocrine disruptors, possible carcinogens, or suspected groundwater contaminants.

Table 4 reveals that in all crops, the total number of pesticide doses per crop cycle is significantly lower for export produce. The total number of Bad Actor pesticides follows the same pattern: significantly more Bad Actor doses are used on produce going to the open domestic market. When one controls for the difference in total doses by looking at Bad Actor pesticides as a percentage of all doses, it is lower for all crops, but the difference is significant only for squash.

More specific differences are revealed in the "highly toxic" and "cholinesterase inhibitor" categories. Organophosphates and carbamates are cholinesterase inhibitors, and most are highly toxic. Thus, the differences in those categories largely reflect the differences between insecticide classes used, as shown in Table 3. The significantly lower number of doses of reproductive and/or developmental toxins in chayote and green beans for export largely reflects lower overall fungicide use, since many common fungicides in the area - e.g., mancozeb, maneb, propineb - are reproductive and/or developmental toxins. The lack of difference in this category for squash produced for the different markets in part reflects that export squash farmers' adoption of newer fungicides like thiophanate-methyl that appear to have the same carcinogenic and reproductive/developmental toxin properties as the older fungicides they replace. It is important to note that no information on carcinogenesis, developmental or reproductive toxicity, or groundwater contamination potential is available to farmers. Pesticide labels only communicate acute toxicity, PHI, registration information, and emergency procedures (see Figure 6).

Figure 7 shows pesticide use as it relates to the residue question for squash produced for the open national market and the export market. The pesticide details section on the left refers to specific active ingredients, their "pesticide group" according to categories in Table 3, and check boxes that show whether or not they are classified as a Bad Actor (see Table 4). The open national market section and the export market sections have the data ordered in the same way, from left to right: number of farmers using it, regulatory information, PHI data, and dose data. The gray fill represents a problematic situation according to the label's use requirements. 


\begin{tabular}{|c|c|c|c|c|c|c|c|c|c|c|c|c|}
\hline & \multicolumn{4}{|c|}{ Chayote -} & \multicolumn{4}{|c|}{$\longrightarrow$ Green Bean } & \multicolumn{4}{|c|}{ Squash } \\
\hline & \multicolumn{2}{|c|}{ Domestic } & \multirow[b]{2}{*}{$\begin{array}{l}\text { Export } \\
(n=20)\end{array}$} & \multirow[b]{2}{*}{$\mathrm{p}^{2}=$} & \multicolumn{2}{|c|}{ Domestic } & \multirow[b]{2}{*}{$\begin{array}{l}\text { Export } \\
(n=11)\end{array}$} & \multirow[b]{2}{*}{$\mathrm{p}^{2}=$} & \multicolumn{2}{|c|}{ Domestic } & \multirow[b]{2}{*}{$\begin{array}{l}\text { Export } \\
(n=28)\end{array}$} & \multirow[b]{2}{*}{$\mathrm{p}^{2}=$} \\
\hline & $\begin{array}{c}\text { Open } \\
(n=13)\end{array}$ & $\begin{array}{l}\text { Controlled } \\
(n=3)^{1}\end{array}$ & & & $\begin{array}{c}\text { Open } \\
(n=22)\end{array}$ & $\begin{array}{l}\text { Controlled } \\
\qquad(\mathrm{n}=3)^{1}\end{array}$ & & & $\begin{array}{c}\text { Open } \\
(n=33)\end{array}$ & $\begin{array}{c}\text { Controlled } \\
(\mathrm{n}=7)^{1}\end{array}$ & & \\
\hline \multicolumn{13}{|l|}{ Insecticide group } \\
\hline $\begin{array}{l}\text { Pyrethroids }(\mathrm{P}) \\
\text { Organophosphates \& carbamates }\end{array}$ & $52 \%$ & $82 \%$ & $63 \%$ & 0.28 & $56 \%$ & $76 \%$ & $55 \%$ & 0.26 & $53 \%$ & $50 \%$ & $41 \%$ & 0.11 \\
\hline$(\mathrm{OP} / \mathrm{C})$ & $40 \%$ & $4 \%$ & $20 \%$ & 0.05 & $26 \%$ & $12 \%$ & $18 \%$ & 0.03 & $33 \%$ & $19 \%$ & $17 \%$ & 0.00 \\
\hline $\begin{array}{l}\text { Synthetic insecticides, new } \\
\text { modes of action }(\mathrm{NI})^{3}\end{array}$ & $5 \%$ & $0 \%$ & $14 \%$ & 0.10 & $6 \%$ & $0 \%$ & $5 \%$ & 0.26 & $4 \%$ & $15 \%$ & $17 \%$ & 0.07 \\
\hline Organochlorines (OC) & $0 \%$ & $0 \%$ & $1 \%$ & 0.16 & $7 \%$ & $0 \%$ & $0 \%$ & 0.09 & $6 \%$ & $0 \%$ & $0 \%$ & $\mathbf{0 . 0 3}$ \\
\hline $\begin{array}{l}\text { Other synthetic insecticides }(\mathrm{OI})^{4} \\
\text { Botanicals, microbials, \& }\end{array}$ & $0 \%$ & $0 \%$ & $1 \%$ & 0.16 & $5 \%$ & $0 \%$ & $6 \%$ & 0.26 & $4 \%$ & $0 \%$ & $3 \%$ & 0.30 \\
\hline organics $(\mathrm{B} / \mathrm{M} / \mathrm{O})$ & $4 \%$ & $14 \%$ & $1 \%$ & 0.35 & $0 \%$ & $12 \%$ & $16 \%$ & 0.01 & $0 \%$ & $15 \%$ & $22 \%$ & $\mathbf{0 . 0 0}$ \\
\hline \multicolumn{13}{|l|}{ Fungicide group } \\
\hline Dithiocarbamates (D) & $41 \%$ & $64 \%$ & $42 \%$ & 0.48 & $50 \%$ & $20 \%$ & $35 \%$ & 0.21 & $45 \%$ & $42 \%$ & $35 \%$ & 0.02 \\
\hline Inorganics $(\mathrm{I})^{5}$ & $42 \%$ & $36 \%$ & $45 \%$ & 0.29 & $9 \%$ & $0 \%$ & $6 \%$ & 0.12 & $24 \%$ & $6 \%$ & $5 \%$ & 0.01 \\
\hline Substituted benzenes (SB) & $11 \%$ & $0 \%$ & $8 \%$ & 0.07 & $16 \%$ & $64 \%$ & $21 \%$ & 0.12 & $19 \%$ & $27 \%$ & $14 \%$ & 0.29 \\
\hline $\begin{array}{l}\text { Benzimidazoles, conazoles, and } \\
\text { thiazoles }(\mathrm{B} / \mathrm{C} / \mathrm{T})\end{array}$ & $5 \%$ & $0 \%$ & $3 \%$ & 0.31 & $13 \%$ & $8 \%$ & $10 \%$ & 0.23 & $8 \%$ & $15 \%$ & $15 \%$ & 0.20 \\
\hline Antibiotics (A) & $1 \%$ & $0 \%$ & $2 \%$ & 0.17 & $3 \%$ & $4 \%$ & $7 \%$ & 0.34 & $0 \%$ & $6 \%$ & $10 \%$ & 0.00 \\
\hline Other synthetic fungicides $(\mathrm{OF})^{6}$ & $0 \%$ & $0 \%$ & $0 \%$ & - & $8 \%$ & $4 \%$ & $14 \%$ & 0.19 & $5 \%$ & $2 \%$ & $16 \%$ & 0.00 \\
\hline Botanicals (B) & $0 \%$ & $0 \%$ & $0 \%$ & - & $1 \%$ & $0 \%$ & $7 \%$ & 0.08 & $0 \%$ & $2 \%$ & $5 \%$ & 0.00 \\
\hline
\end{tabular}

Table 3: Groups of insecticides and fungicides used by market segment, Northern Cartago and the Ujarrás Valley, 2003-04. Source: Author's farmer surveys, 2003-04.

${ }^{1}$ Data on controlled national market production are de-emphasized with a light gray typeset because sample sizes are small and are not included in the statistical tests.

${ }^{2}$ Two-tailed t-tests assuming unequal variance, comparing open domestic and export categories highlighted with a gray background.

${ }^{3}$ As defined by Nauen and Bretschneider (2002): acetamiprid, chlorfenapyr, cyromazine, diflubenzuron, fipronil, imidacloprid, novaluron, teflubenzuron, and thiamethoxam

${ }^{4}$ Includes cartap, metaldehyde, and thiocyclam.

${ }^{5}$ Fungicides without carbon based on the elements copper or sulfur.

${ }^{6}$ Includes cymoxanil, dimethomorph, flutolanil, metalaxyl-m (mefenoxam), oxycarboxin, captan, folpet, fosethyl-al, tolclofos-methyl, and propamocarb. 


\begin{tabular}{|c|c|c|c|c|c|c|c|c|c|c|c|c|}
\hline & \multicolumn{4}{|c|}{ Chayote } & \multicolumn{4}{|c|}{${ }_{-}$Green Bean } & \multicolumn{4}{|c|}{ Squash } \\
\hline & \multicolumn{2}{|c|}{ Domestic } & \multirow[b]{2}{*}{$\begin{array}{l}\text { Export } \\
(\mathrm{n}=20)\end{array}$} & \multirow[b]{2}{*}{$p^{2}=$} & \multicolumn{2}{|c|}{ Domestic } & \multirow[b]{2}{*}{$\begin{array}{l}\text { Export } \\
(\mathrm{n}=11)\end{array}$} & \multirow[b]{2}{*}{$\mathrm{p}^{2}=$} & \multicolumn{2}{|c|}{ Domestic } & \multirow[b]{2}{*}{$\begin{array}{l}\text { Export } \\
(\mathrm{n}=28)\end{array}$} & \multirow[b]{2}{*}{$\mathrm{p}^{2}=$} \\
\hline & $\begin{array}{c}\text { Open } \\
(\mathrm{n}=13)\end{array}$ & $\begin{array}{l}\text { Controlled } \\
\qquad(\mathrm{n}=3)^{1}\end{array}$ & & & $\begin{array}{l}\text { Open } \\
(\mathrm{n}=22)\end{array}$ & $\begin{array}{l}\text { Controlled } \\
\qquad(\mathrm{n}=3)^{1}\end{array}$ & & & $\begin{array}{l}\text { Open } \\
(\mathrm{n}=33)\end{array}$ & $\begin{array}{l}\text { Controlled } \\
\qquad(\mathrm{n}=7)^{1}\end{array}$ & & \\
\hline Total pesticide doses & 104.4 & 126.7 & 72.7 & 0.02 & 23.6 & 15.3 & 18.9 & 0.09 & 46.11 & 25.86 & 30.05 & 0.01 \\
\hline \multicolumn{13}{|l|}{ Bad actor doses: } \\
\hline Highly toxic & 19.5 & 2.2 & 10.9 & 0.12 & 3.5 & 1.3 & 1.8 & $\mathbf{0 . 0 7}$ & 7.2 & 2.0 & 3.5 & 0.01 \\
\hline Cholinesterase inhibitor & 20.8 & 2.2 & 8.4 & $\mathbf{0 . 0 3}$ & 2.1 & 0.7 & 0.4 & 0.02 & 5.3 & 1.4 & 1.8 & 0.01 \\
\hline Carcinogen & 18.6 & 0.0 & 16.4 & 0.34 & 7.8 & 6.0 & 5.5 & 0.19 & 12.2 & 7.4 & 9.6 & 0.14 \\
\hline $\begin{array}{l}\text { Developmental or reproductive } \\
\text { toxin }\end{array}$ & 33.1 & 45.2 & 20.2 & 0.04 & 9.9 & 2.7 & 5.2 & 0.02 & 15.8 & 10.7 & 12.6 & 0.21 \\
\hline $\begin{array}{l}\text { Groundwater contaminant } \\
\text { Bad Actor total (any of the }\end{array}$ & 0.0 & 0.0 & 0.0 & - & 0.0 & 0.0 & 0.1 & 0.33 & 0.0 & 0.3 & 0.0 & - \\
\hline above criteria) & 55.0 & 47.3 & 33.9 & 0.04 & 15.5 & 9.3 & 10.3 & 0.04 & 29.0 & 17.9 & 17.8 & 0.01 \\
\hline \multicolumn{13}{|c|}{ Bad Actor doses as percentage of all doses: } \\
\hline Highly toxic & $18 \%$ & $1 \%$ & $14 \%$ & 0.21 & $15 \%$ & $9 \%$ & $9 \%$ & 0.08 & $18 \%$ & $13 \%$ & $11 \%$ & 0.03 \\
\hline Cholinesterase inhibitor & $19 \%$ & $1 \%$ & $11 \%$ & 0.06 & $10 \%$ & $4 \%$ & $6 \%$ & 0.09 & $14 \%$ & $10 \%$ & $5 \%$ & 0.01 \\
\hline Carcinogen & $17 \%$ & $0 \%$ & $21 \%$ & 0.24 & $28 \%$ & $39 \%$ & $35 \%$ & 0.24 & $26 \%$ & $25 \%$ & $29 \%$ & 0.22 \\
\hline $\begin{array}{l}\text { Developmental or reproductive } \\
\text { toxin }\end{array}$ & $30 \%$ & $36 \%$ & $27 \%$ & 0.29 & $37 \%$ & $19 \%$ & $25 \%$ & $\mathbf{0 . 0 3}$ & $33 \%$ & $35 \%$ & $39 \%$ & 0.27 \\
\hline $\begin{array}{l}\text { Groundwater contaminant } \\
\text { Bad Actor total (any of the }\end{array}$ & $0 \%$ & $0 \%$ & $0 \%$ & - & $0 \%$ & $0 \%$ & $0 \%$ & 0.23 & $0 \%$ & $1 \%$ & $0 \%$ & - \\
\hline above criteria) & $51 \%$ & $38 \%$ & $44 \%$ & 0.16 & $61 \%$ & $63 \%$ & $58 \%$ & 0.34 & $64 \%$ & $63 \%$ & $55 \%$ & 0.06 \\
\hline
\end{tabular}

Table 4: Use of Bad Actor pesticides per crop cycle by market segment, Northern Cartago and the Ujarrás Valley, 2003-04. Source: Author's farmer surveys, 2003-04.

${ }^{1}$ Data on controlled national market production are de-emphasized with a light gray typeset because sample sizes are small and are not included in the statistical tests.

${ }^{2}$ Two-tailed t-tests assuming unequal variance, comparing open domestic and export categories highlighted with a gray background. 


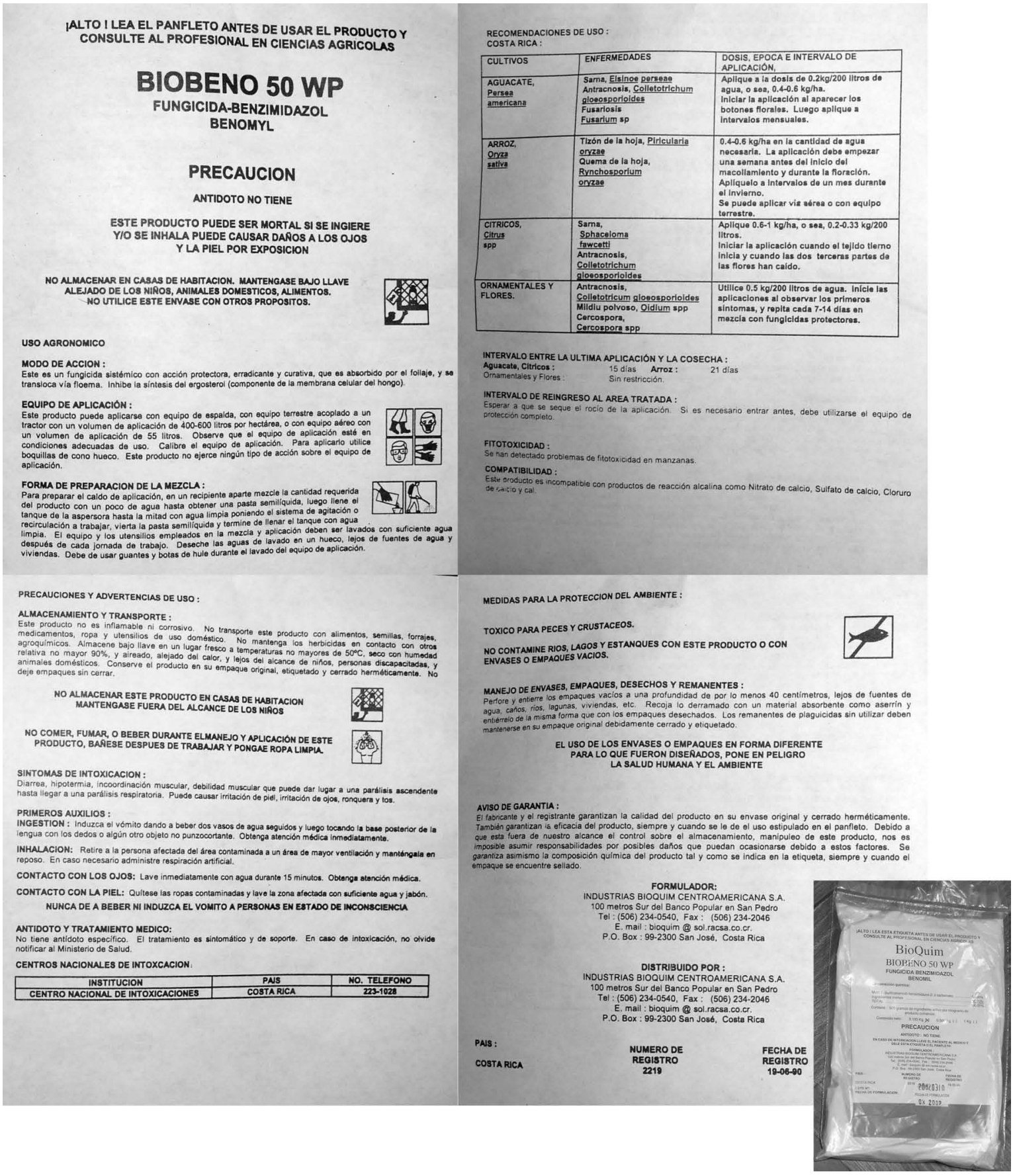

Fig. 6: All four leaves of the pesticide label for one commercial formulation of benomyl as sold in Northern Cartago. There is no indication on this or any other label that benomyl is a possible carcinogen and a developmental or reproductive toxin (as listed on California's Proposition 65 list).

The dose section on the far right side of each market segment section plots the doses used by each farmer in relation to the maximum recommended dose on the label, which is designated as 100 percent. The average is given left of the dose plot. A gray fill means that the dose used exceeds the label's requirements. Looking at the dose data as a whole, farmers' respect of recommended doses is actually quite high, in both markets. On average, only five of 48 (10.4 percent) of the active ingredients (ai's) used for open national market squash were applied in excess of the dose on the label. Of these, four are averages from an $n$ of one. For the export market, on average only three of 59 (5.1 percent) were applied as overdoses, and all are also averages from an $n$ of one. 
Galt

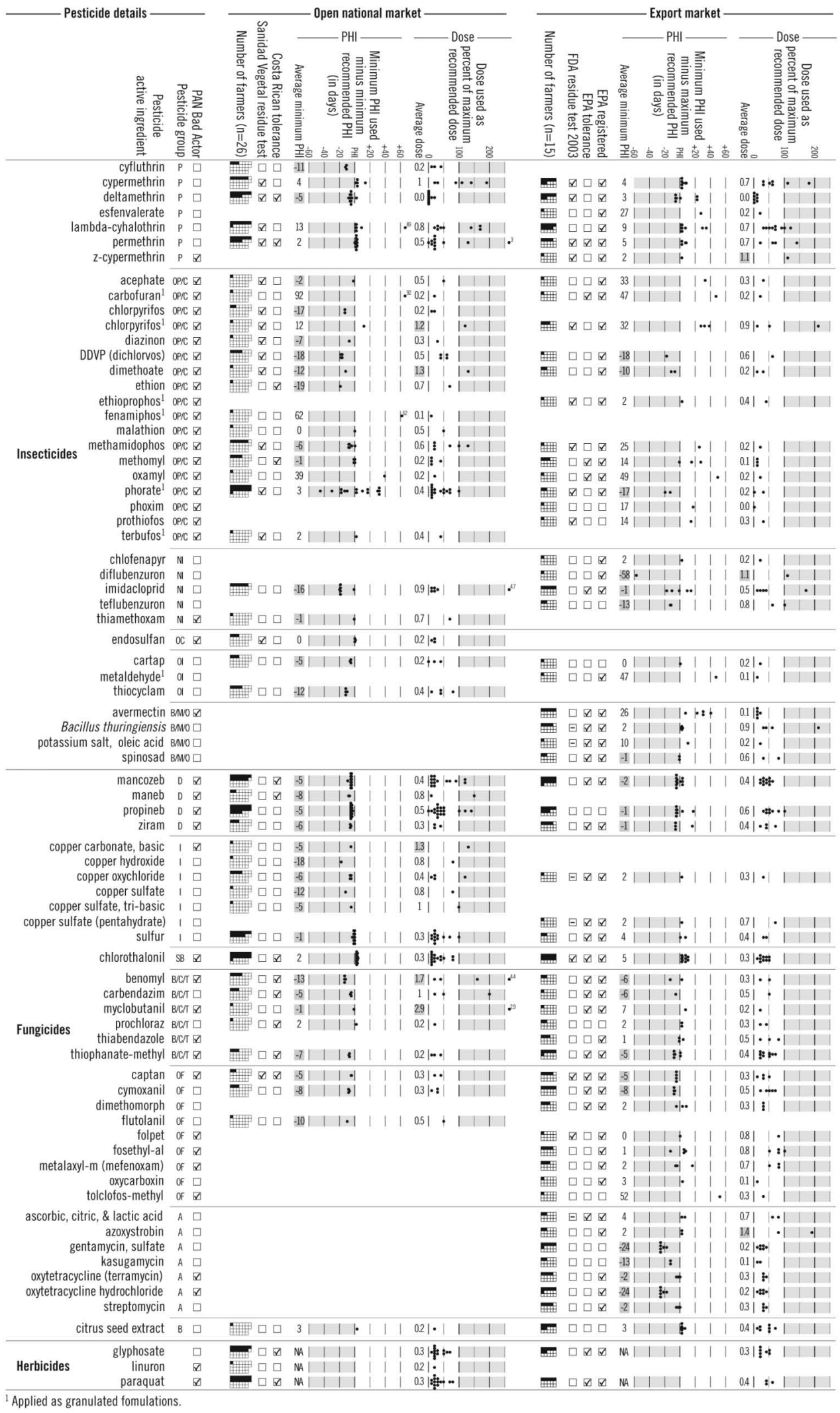

Fig. 7: Pesticide use on open national market and export squash in relation to regulation, Northern Cartago and the Ujarrás Valley, 2003. Sources: Author's farmer surveys 200304 \& Costa Rican pesticide labels; La Gaceta (1997) \& Rodríguez Solano (1994); EPA (2004) \& FDA (2006). 
The PHI section in Figure 7 plots the result of subtracting the minimum required PHI on the label from farmers' reported minimum PHIs. ${ }^{22}$ Thus, a zero means that the farmer respects the minimum PHI exactly, while a negative number means that PHI is violated, i.e., the farmer did not wait long enough between spray and harvest. The average appears to the left of the PHI plot. The gray background means that it violates the PHI required by the Costa Rican label. In contrast to general respect for dose, PHIs for most pesticides are commonly violated due to the continual harvests, high pest and disease pressures, and an almost exclusive reliance on agrochemicals for pest problems. Thirty-one of 45 , or 68.9 percent, of the average minimum PHIs violate the label requirements in open national market pesticide use. In contrast, 20 of 56 (35.7 percent) of the average minimum PHIs for the export market are in violation of required PHIs. Thus, export farmers are less likely to be in violation, but compliance is far from perfect.

Regulatory information for each market appears to the left of the dose and PHI plots. "Costa Rican tolerance" refers to the existence of a legal tolerance for the pesticide on the specific crop, as established in La Gaceta (1997). While all pesticides are registered for some use in Costa Rica, of the pesticide ai's used by open national market squash farmers, 14 of 48, or 29.1 percent, are registered specifically for use on squash in Costa Rica. An additional 13 have tolerances set for other cucurbits - chayote, cucumber, or melon but not squash. "Residue test" refers to whether the pesticide would be detected by Sanidad Vegetal's pesticide residue testing program (Rodríguez Solano 1994). These tests would find only pyrethroids, organophosphates, organochlorines, and almost no fungicides. The regulatory situation in export market squash is relatively similar. Of the pesticide active ingredients used, 24 of 59 (40.7 percent) are registered or exempt for tolerances on squash. However, 49 of 59 (83.1 percent) are registered for some agricultural use in the U.S. FDA residue testing is similar in coverage to Costa Rican tests: it would find many pyrethroids, organophosphates, and carbamates, but would miss most fungicides.

Differences in the types of pesticides used are evident between the market segments. As Table 3 showed, organophosphates and carbamates are more commonly used in the open national market. This is especially true of DDVP, methamidophos, and phorate, the PHIs of which are commonly not respected due to the consistently harvested nature of the crop. Export farmers also rely considerably more on the botanical, microbial, and organic insecticides, especially avermectin and Bacillus thuringiensis. Fungicide use is very similar between the market segments, except export farmers' much heavier reliance on the broad category of "other synthetic fungicides," which is notable in that many are not Bad Actor pesticides, unlike the older dithiocarbamates, that are generally probable carcinogens. Another difference is the use of antibiotic fungicides in the export market segment. Most of these are also not Bad Actor pesticides, with the exceptions of the oxytetracyclines, which are developmental or reproductive toxins.

The general pattern from Figure 7 suggests less caution on the part of national market farmers vis-àvis residues, as was also evinced during follow-up interviews. This lower level of caution is evident in less respect for PHIs of, higher dependence upon, and more frequent use of organophosphates and carbamates, and less use of botanical, microbial, and organic insecticides, which avoid residue problems but are very expensive relative to synthetic agrochemicals (see Table 2).

\section{Specific cases of pesticide residue problems for the open national market}

While not representing the "average" condition, the illustrative cases described below also demonstrate the double standard of pesticide residue regulation and its manifestations in farmers' management. Raúl, a chayote farmer, produces the negro variety for the national market, and the quelite variety for export. He has two different systems of insecticide use for the different markets. For national market chayote he uses mostly organophosphates - chlorpyrifos and a pesticide that is a combination of dimethoate and cypermethrin - with a minimum PHI of 2 days. The labels specify 20 days for chlorpyrifos and 7 to 15 days for the combination pesticide. For his export chayote, he uses only pyrethroids cypermethrin, deltamethrin, lambda-cyhalothrin, and permethrin - also with a minimum PHI of 2 days. These practices would likely translate into higher pesticide residue burdens on the national market produce.

The residue double standard is also evident in the practices of some farmers who generally produce only for export. Vidal, who produces chayote for export, said that he sometimes applies residual, proscribed pesticides like methamidophos or carbofuran for very intense pest outbreaks in export chayote. I asked what he did with the harvest, since chayote is generally harvested every few days for a period of nine months or more:

Vidal: Well, when it is in full harvest, it is always in harvest, always in harvest. It doesn't stop. For this reason one is very careful, because of the danger you run. If it comes out contaminated, they close the export market to you. They won't receive chayote for a period of time, until ... methamidophos or the poison has already passed its cycle.

$R G$ : In harvest, it doesn't go for export?

\footnotetext{
${ }^{22}$ The minimum PHI was derived from asking farmers about spraying and harvest times, and then using the lowest number of days that they wait between application and harvest.
} 
Rubén, interrupting the conversation, saying jokingly: It goes to kill Ticos.

Vidal, nodding his head in agreement, also jokingly: It just goes to kill Ticos.

In the above conversation, Rubén, an export squash farmer, had introduced me to his neighbor Vidal and had then gone to work on his own farm. He returned when he was done with the task, and sat down beside Vidal and I under the tin roof shed in order to get out of the rain that had started to fall. He had heard only a minute or so of our conversation, but understood where it was going. Without Rubén's return, it might have been hard for Vidal to admit that immediately after the application of very residual organophosphate or carbamate insecticides he sells his chayote to the national market instead of the export market. Pablo, another chayote export farmer, reported using the same practice during the survey. And another chayote farmer during our discussion pointed out that he uses methamidophos, but only on his green beans for national market.

The two export chayote farmers who admitted to selling highly contaminated produce to the national market account for 10 percent of the export chayote farmers in the survey. It is important to note that they more or less volunteered this information to me, and that I did not specifically probe other farmers to try to get them to admit this practice. I suspect that more export chayote farmers might follow a similar strategy, though few are willing to talk about it due to the delicate nature of the subject. Thus, for what is likely an important minority of export chayote farmers, the national market serves as an outlet for chayote that export farmers and exporters consider to be too contaminated by pesticide residues to be safe to export. This is similar to produce of second-tier aesthetic quality being routed to the national market, but has greater implications for the health of consumers.

Unlike some export chayote farmers, all export squash farmers aim their squash production for the export market. Because two exporters tightly control the export and national market for their produce, export squash farmers do not have the myriad national market outlets that chayote farmers can use, so they sell all their produce to either exporter. These firms grade the produce, with the lower grades going to various channels in the controlled national market, and sometimes at ferias. Managers of the exporters insisted that this is determined entirely by aesthetic and size requirements and that they do not consider or test for residues in making the decision. Thus, the squash sold in the controlled national market by the two exporters are produced in the same manner as those that are exported (see also Breslin 1996).

The difference in potential residues on squash for the different markets arises from some national market squash farmers engaging in pesticide use that is completely proscribed by exporters, especially the use of methamidophos during harvest. As noted above, consecutive use of organophosphates, especially methamidophos during the harvest phase, can result in the high concentration of pesticides in the plant.

Miguel uses methamidophos once every two weeks on his squash during harvest time. With his twice-weekly harvests, there is a maximum of 4 days between application and harvest, though the label requires at least 21 days. Similarly, Cristóbal sprays methamidophos once a week in squash for the entire cycle, for a total of 18 applications. He reported waiting three to four days between the spray and the harvest, and that the individual squashes require about a month to develop fully. This means that each squash as it develops receives four doses of methamidophos at the high rate he uses, $1.143 \mathrm{~kg}$ ai/ha (the recommended dose on the label is 0.3 to $0.9 \mathrm{~kg}$ ai $/ \mathrm{ha}$ ). With the practices of both of these farmers, residue levels likely build up to levels higher than those shown in Figure 5 since applications are more frequent. ${ }^{23}$ Another national market farmer uses endosulfan, an organochlorine insecticide, on his squash every week. As with frequent methamidophos applications, these frequent applications likely lead to very high residue levels in his squash. These three farmers, whose squash is likely to be highly contaminated with pesticide residues that can pose risks of consumer poisoning, represent 11.5 percent of the national market squash farmers in the survey. Other national market squash farmers use highly residual pesticides in harvest, but not as frequently.

Given the difference in farmers' pesticide use practices, exported squash and chayote likely have lower insecticide residue levels on average than squash and chayote produced exclusively for the open national market. More important from a consumer poisoning standpoint, there may be extremely high levels of residues in about ten percent of national market cucurbits.

\section{Discussion and Conclusions}

I would like to discuss and conclude on three main points. The first is about how researchers explain the frequent and high levels of pesticide residues on produce for national markets in developing countries. Gupta (2004: 89) notes that "there is every reason to properly educate farmers for judicious use of pesticides." Ecobichon (2001: 32) discusses legislation and accompanying regulation as a short-term solution to pesticide residue problems, but concludes "the long-term solution to pesticide problems is education." The only available report from Costa Rica's national pesticide residue laboratory

\footnotetext{
${ }^{23}$ Although this farmers' production occurs outside and is therefore exposed to rainfall that may wash off some residues, methamidophos is a systemic insecticide that is translocated throughout the plant, so residues are likely to still be very high.
} 
repeats the common assumption of those who conduct residue analyses. Rodríguez Solano (1994: 50) describes visits to farms where violative residues have been found,

with the goal of establishing the reason for excessive pesticides residues and collaborating with the producer, checking application equipment and the dose of pesticides used, evaluating pest problems, and training them in good use of pesticides.

The assumption of these corrective actions is that violative residues are a technical problem that can be fixed by training the farmer and reviewing her/his application equipment. While these actions might help, a technical explanation is inadequate because it does not deal with the "simple reproduction squeeze" (cf. Watts 1983) of the small vegetable farmer in Costa Rica facing declining or fluctuating prices. As petty commodity producers with almost no subsistence activities, Costa Rican vegetable farmers depend upon the prices they receive for their produce for basic household reproduction. This situation creates a temptation to use the more effective and residual organophosphates and carbamates to keep production costs low while still protecting the crop. Pesticides that leave lower levels of residues are generally more expensive or less effective over time, and the unpredictable nature of prices in the national market means that farmers must keep costs low in case harvests occur during times of low farm gate prices, which frequently occur. The biological nature of the consecutively harvested vegetables intersects with the simple reproduction squeeze to result in high levels of residues of organophosphates and carbamates, which offer the most cost-effective, short-term ecological intervention into the pest problem farmers face.

The "farmer ignorance thesis" arises from a technocratic worldview ignorant of, or apathetic to, the economic and ecological conditions of production to which political ecology pays special attention. Just as Blaikie (1988) critiques the discourse of widespread anthropogenic soil erosion in Nepal as arising in part from observers' road-biased "rural tourism," the discourse on farmers' lack of caution stems from the most striking visual aspect of pesticide use in developing countries: the lack of use of protective equipment, which observers often describe more generally as a complete lack of caution. This striking visual impression is easily found in Northern Cartago and the Ujarrás Valley. A quick drive through the area will result in glimpses of practices that in varying degrees resemble those shown in Figure 8. But a finer-grained story of pesticide use not easily seen by the casual observer - farmers' decisions about pesticide type, dose, PHI, etc. - results in important nuances and qualifications to the view of widespread lack of caution.

By spending a large amount of time with farmers and discussing pesticide use in the context of the survey and outside of it, I learned a great deal about the forms of caution farmers use when spraying pesticides. Most farmers, even in the open national market, take into account the residue question, so it is not just regulatory risk that makes farmers cautious about pesticide use. Figure 7 reveals that even open national market farmers who face little to no effective regulatory pressure to rationalize pesticide use still exercise some cautions about leaving residues. While this could be the result of experimentation, in that farmers used different doses and found that overdoses did not work better than the recommended does, it is also due to a basic concern for the well being of others, since most farmers feel that pesticide residues can harm the health of those who consume their produce. For example, Marcos, a relatively wealthy farmer in Buenos Aires de Pacayas, discussed spraying insecticides on national market squash: "I almost don't spray it with insecticides. If you spray pesticides, you have a poisoned squash. The problem is residues after [just] two to three days" (July 28,2003 ). As a caveat, there are certainly some national market farmers who admitted to not caring about residues, or to being economically driven enough to spray and harvest soon afterward, but most profess a knowledge of residues and a sense of obligation toward the consumer. Grossman's $(1992,1998)$ work similarly points to St. Vincentian farmers' concern about exposing their families and national market consumers to toxic pesticide residues. Concern about consumer exposure to residues is the first layer of the causes that create caution over residues, and pertains to all market segments in Costa Rican vegetable production. Export farmers have the same concern, but layered on top of it are exporters' enforcement mechanisms, making it likely that export farmers will exercise more caution vis-à-vis residues than national market farmers.

The implications of overturning the "farmer ignorance thesis" with the political ecological understanding presented here are profound. I have argued that the volatile national market and lack of national market regulation create ideal conditions for high levels of residues: farmers will turn to more persistent, generally older and more toxic pesticides to adapt to the simple reproduction squeeze of falling or uncertain prices for the petty commodities they produce, commodities upon which their livelihoods depend. In contrast, a guaranteed farm-gate price for produce allows farmers to plan for and to afford the higher input costs of the least residual pesticides. This is because they do not have to constantly aim for the lowest costs while still protecting their crop. 


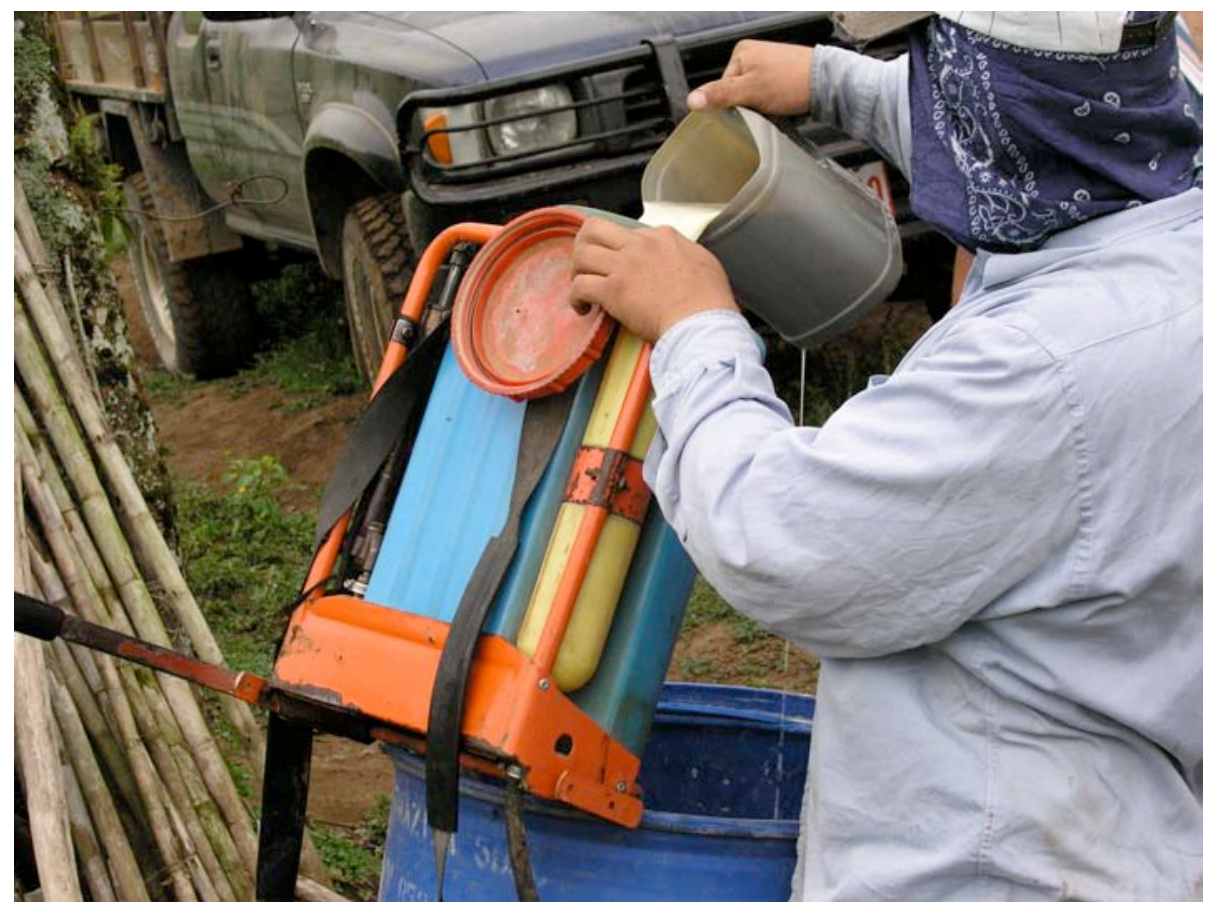

Fig. 8: A farm worker mixes a batch of methamidophos, mancozeb, and foliar nutrients for a pesticide application in national market potatoes. The widespread lack of protective equipment is very problematic, but does not mean that all forms of caution are ignored in pesticide applications in developing countries (author).

Thus, the relatively high levels of farmers' use of organic, microbial, and botanical insecticides on export squash and export green bean can be understood in the context of their specific market conditions: (1) their farm gate price is fixed and has moved incrementally upward over the years, and (2) their exporters are adamant about avoiding residues on exported produce. As Rodrigo, an export squash farmer, pointed out, "you have a guaranteed price, you know that it is a fixed price. So, you can take care not to spray residual products" (Interview, December 10, 2003). Export chayote farmers do not receive a fixed price, and it has even declined over time in the last few years, but they are still pressured by exporters to avoid residues. I argue that as a consequence of the declining price they do not use the least residual organic, microbial, and botanical insecticides like other export farmers, but because of some control by exporters, they instead rely more on the pyrethroids.

Understanding that pesticide residues are strongly connected to petty commodity producers' economic well-being suggests that the creation of a fair trade vegetable market that offers fixed prices and provides guidelines on lower-risk pesticide use could contribute to solving residue problems in exported and eventually domestic market produce in developing countries. This is not the only reason to pursue fair trade vegetables, but can be used to powerfully link consumers' interests in low residues to farm family economic interests.

My second conclusion addresses the changing forms of agro-food governance. The increasing market power of supermarkets, and the corollary of possible private standard regulation in developing countries, are severely understudied. This segment should be understood in relation to the export and open market segment. In many cases, it may be more closely related to the open market segment, or, alternatively, it may create, through stricter control, a market segment that might materially reflect the perceptions of supermarkets as places of high quality food (cf. Murdoch et al. 2000). Undoubtedly, local specificities in terms of firms' pesticide policing, national regulations, and other factors that contingently mediate the effects of global or transnational linkages will be an important part of the explanation of differences and similarities between market segment.

These market segments and their governance will continue to be shaped by civil society actors. Pesticide residues remain a contested form of food contamination, and interpretations of analytical chemists of their own residue analyses are likely to be increasingly questioned in developing countries. For example, in writing of the Costa Rican residue laboratory's analysis, Rodríguez Solano (1994: iv) interprets the fact that "11 percent of the samples have residue levels above the permitted levels" as being "sufficiently low, in that it shows that the problems of poor management of pesticides are not as alarming as is believed." Why this is "sufficiently low" is unclear. If we assume the average Costa Rican consumes five servings of 
vegetables every day (which is a low estimate based on my observations of families with whom I lived and ate), they will eat a vegetable with violative residues every other day on average. I would guess that many of those consuming these vegetables would object to being exposed to rather high levels of residues, and especially to the idea presented here that the less-contaminated vegetables tend to be exported. Ultimately, designations of "sufficiently low" need to be made by informed citizens, not technical experts. The discussion of exposure and risk ultimately revolve around questions about who receives the benefits and who bears the cost, and about whether those most affected become part of the decision-making process (Irwin 1995). Increasingly active social movements around food in developing countries, including struggles over its production and consumption, will influence these decisions and interpretations.

My third conclusion concerns the health and equity aspects of consumption shaped by the pesticide residue double standard. Data presented here suggest that Costa Rican consumers are exposed to higher levels of more harmful residues in their produce, a situation that reflects findings from other countries and comparisons of residues levels across nations. What this ultimately means for consumer health is more difficult to say; as environmental justice scholars point out, there remains a strong need to link differential exposures to toxins to health impacts (Brulle and Pellow 2006). I attempt to tread a middle ground on the issue. On the one hand, an important minority of national market farmers use methamidophos in a way that likely results in high levels of residues. I suggest that this probably results in cases of consumer pesticide residue poisonings in Costa Rica, and that consumers and doctors almost always attribute these to bacteria (arguably the primary cause of food poisoning). The case of Hong Kong's methamidophos poisonings serves to highlight the potential existence of such poisonings from residues on produce in unregulated markets. There are other possible health consequences of exposures to high levels of residues, including cancer and harm to the immune, nervous, endocrine, and reproductive systems (Porter et al. 1999). On the other hand, I am not arguing that these residues are a circumstance more dire than widespread poverty, global warming, or species loss, but rather I seek to acknowledge the unequal distribution of residues due to uneven regulation, and argue that these likely have real health consequences.

I am on more solid footing in arguing that the pesticide residue 'double standard' has real effects on farmers' pesticide use, and challenges our interpretations of inequity arising from the global economy. While many farmers focusing production on the open national market demonstrate caution about residues, the lack of national market enforcement means that squash and chayote farmers selling on the open national market rely more on organophosphate and carbamate insecticides that are proscribed for export, and use them closer to the harvest period as compared to export squash and chayote farmers. If we situate our understanding of environmental justices in real world events (Low and Gleeson 1998), the macro-political economic system and its uneven regulation of pesticides at the level of the state are filtered through the "micro-events" of farmers pesticide spraying decisions detailed above, which ultimately results in the unequal patterns of exposure to pesticide residues between the global North and global South.

Decades ago, Wolf (1982) noted the systematic privilege in the world system enjoyed by the former colonial powers. More recently, the concepts of male privilege and white privilege in women's studies and critical race studies (McIntosh 1988) have helped our understanding of broad patterns of environmental injustices. Pulido (2000), for example, operationalizes the concept of white privilege to show one powerful mechanism by which environmental injustices in exposure to toxins originated and persists in Los Angeles. As Wolf (1982) showed, the differences in privilege and marginality clearly extend across a larger scale, that between global North and global South. The power differential at a more global scale - what we might call "Northern privilege" - is felt and demonstrated in various ways currently. In the depiction of events in the 1994 Rwandan genocide, the 2005 film Hotel Rwanda shows the arrival of European and U.S. troops. The Tutsi Rwandans seeking safety in the hotel initially view this as the West finally sending help to stop the genocide, a relatively minor commitment since the atrocities were being committed mostly by machete and orchestrated by radio broadcasts. Instead, the Western soldiers evacuate the Europeans and Americans and leave the country and its Tutsis to the orchestrated genocide, resulting in at least one million deaths.

In addition to these political manifestations of Northern privilege, there are examples in the market system, in opposition to neoclassical economics' understanding of markets as neutral institutions. For example, Northern privilege was expressed by the infamous World Bank document by chief economist Lawrence Summers, which recommended the disposal of toxic waste in developing countries, since, measured in earning potential, human life there is worth far less. The memo states: "I think the economic logic behind dumping a load of toxic waste in the lowest wage country is impeccable and we should face up to that" (Summers 1991, cited in Bullard 1993: 20). Similarly, the environmental and health impacts of export agriculture and other primary production activities have long been borne by the South as its people pay the environmental, health, and economic costs of economies oriented to serve the North.

Yet, beyond cases of dumping and extractive primary production activities, the effects of Northern privilege as codified in uneven regulation - and the resulting environmental and consumption inequalities - also manifest themselves in daily land management of vegetable farmers in Costa Rica. Some farmers spray produce destined for consumption by their compatriots with the most toxic pesticides or will wash national market produce in spray tanks, yet very few employ these practices when selling to export markets. This injustice resulting from the pesticide residue double standard is routinized in many farmers' production 
practices.

These findings challenge preconceptions of those of us concerned with injustice in the world system who view pesticide problems arising from the very existence of export production. In the Costa Rican case, the view of inherently problematic export production has arisen from the brutal realities of decades of banana production. Certainly the banana fields of Costa Rica have witnessed massive injustice and environmental destruction, including widespread deforestation (Vandermeer and Perfecto 1995) and pesticide contamination (Thrupp 1991a), violent repression in response to workers' attempts to organize (Jiménez 1995), sterilization of workers from pesticides known to cause sterility (Barrantes 2001; Weir and Matthiessen 1989), and exposure of workers to other highly toxic, carcinogenic, and teratogenic pesticides that result in acute poisonings and chronic ills like cancer (Aguero Rojas 1998; Sass 2000; Wesseling et al. 1996). I do not dismiss or minimize these injustices, but I note that we have conceived of export production as imposing injustice, while in our unexamined binary model the national market production is equated with justice since it provisions national citizens. We need to move beyond this dichotomous conception of pesticide injustice in the world system to recognize that injustices resulting from pesticides and other toxins in developing countries are multi-faceted and create diverse outcomes in different places and at different scales. In other words, export production in the banana zone results in imposed and unjust health risks to workers, while in Costa Rican vegetable systems produce with lower levels of pesticides is exported while produce with greater prevalence and higher levels of residues goes to feed Ticos.

While recognizing these different outcomes and their contradictions, I also argue that these situations of injustice are linked - Northern privilege structures both. In the case of bananas, consumers in the North can demand perfect produce year-round and never have to be bothered by understanding the consequences of the production system on the environment or workers. Similarly, and as consciousness changes, consumers in the North can demand that their governments and/or their supermarkets monitor pesticides in food imports, which, while satisfying personal interests (cf. Szasz 2007) rather than expressing solidarity with farmers or workers in the global South, can lead to pesticide use rationalization in export production systems. Citizens in developing countries can make the same demands about residues and increasingly do so, but the state is not as responsive, or it lacks the resources to prioritize residue testing. Lamentably, the privileges of the North, accumulated during the colonial period, remain entrenched in the post-colonial period and continue to be manifested in the "micro-events" of Costa Rican farmers' pesticide use.

\section{References Cited}

Abeysekera, W.A.T.

1988. Pesticide use in the food production sector in Sri Lanka. In Use of pesticides and health hazards in the plantation sector, pp. 12-37, edited by Congress Labour Foundation. Colombo, Sri Lanka: Friedrich-Ebert-Stiftung.

Aguero Rojas, Mercedes.

1998. Indagan efecto de plaguicida en niños: Extraños males afectan a hijos de bananeros. Al Día, 7 April 1998, 3.

Aguilar-del Real, Ana, Antonio Valverde-García, and Francisco Camacho-Ferre.

1999. Behavior of methamidophos residues in peppers, cucumbers, and cherry tomatoes grown in a greenhouse: Evaluation by decline curves. Journal of Agricultural and Food Chemistry 47:3355-8.

Ames, Bruce N., Margie Profet, and Lois Swirsky Gold.

1990. Dietary pesticides (99.99\% all natural). Proceedings of the National Academy of Sciences of the United States of America 87 (19): 7777-81.

Anonymous.

1998. Análisis de residuos de plaguicidas en seis diferentes hortalizas de consumo nacional procedentes de diversas regiones de Nicaragua. For Export (Nicaragua) Septiembre-Octubre:29-31.

Arbona, Sonia I.

1998. Commercial agriculture and agrochemicals in Almolonga, Guatemala. Geographical Review 88 (1):47-63.

Baker, B.P., C.M. Benbrook, Edward Groth, III, and K. Lutz Benbrook.

2002. Pesticide residues in conventional, integrated pest management (IPM)-grown and organic foods: Insights from three US data sets. Food Additives and Contaminants 19 (5):427-46.

Balsevich, F., J. Berdegué, L. Flores, D. Mainville, T. Reardon, L. Busch, and L. Unnevehr. 2003. Supermarkets and produce quality and safety standards in Latin America. American Journal of Agricultural Economics 85 (5):1147-54.

Barquero S., Marvin. 1990. MAG niega peligro por agroquímicos. La Nación, 15 November 1990, 6A.

Barquero S., Marvin. 1999. Guerra a los plaguicidas. La Nación, 24 April 1999, 25 A. 
Barquero S., Marvin, and Patricia Navarro.

1990a. Anarquía en control de agroquímicos: Los ministerios de Salud y de Agricultura no se ponen de acuerdo sobre el registro de plaguicidas. La Nación, 15 November 1990, 5A.

Barquero S., Marvin, and Patricia Navarro.

1990b. Residuos superan límites en muestras de vegetales: Ocho de nueve muestras de vegetales analizadas, con niveles altos de residuos de agroquímicos, procedían de Cartago. La Nación, 13 November 1990, 6A.

Barrantes, Orlando.

2001. Resumen de la lucha por los derechos de los trabajadores bananeros y sus familias expuestos al DBCP (Nemagón). In El uso de plaguicidas y su relación con el desarrollo en Costa Rica: Ponencias, preguntas-respuestas y conclusiones, pp. 53-5, edited by M. Amador. San José, Costa Rica: Proyecto PLAGSALUD, Foro Emaús, Rel-UITA.

Bebbington, A. J., and S.P.J. Batterbury.

2001. Transnational livelihoods and landscapes: political ecologies of globalization. Ecumene 8 (4):369-80.

Benbrook, C.M.

2002. Organochlorine residues pose surprisingly high dietary risks. Journal of Epidemiology and Community Health 56:822-3.

Berdegué, Julio A., Fernando Balsevich, Luis Flores, and Thomas Reardon. 2005. Central American supermarkets' private standards of quality and safety in procurement of fresh fruits and vegetables. Food Policy 30 (3):254-69.

Blaikie, Piers.

1985. The political economy of soil erosion in developing countries. London: Methuen.

Blaikie, Piers.

1988. The explanation of land degradation in Nepal. In Deforestation: Social dynamics in watersheds and mountain ecosystems, pp. 132-58, edited by J. Ives and D.C. Pitt. London: Routledge.

Blaikie, Piers, and Harold Brookfield. 1987. Land degradation and society. London: Methuen.

Breslin, Patrick. 1996. Costa Rican farmers find their mini-niche. Grassroots Development 20 (2):26-33.

Brulle, Robert J., and David N. Pellow.

2006. Environmental justice: human health and environmental inequalities. Annual Review of Public Health 27:103-24.

Bryant, Raymond L., and Michael K. Goodman. 2004. Consuming narratives: the political ecology of 'alternative' consumption. Transactions of the

Bull, David. Institute of British Geographers 29 (3):344-66.

1982. A growing problem: pesticides and the Third World poor. Oxford: OXFAM.

Bullard, Robert D.

1993. Anatomy of environmental racism and the environmental justice movement. In Confronting environmental racism: Voices from the grassroots, pp. 15-39, edited by R.D. Bullard. Boston: South End Press.

Carazo, Elizabeth, Manuel Constenla, Gilbert Fuentes, and Pran Nath Moza. 1984. Studies of methamidophos-C-14 in Costa Rican vegetables and soils. Chemosphere 13 (8):939-46.

Carney, Judith.

2004. Gender conflict in Gambian wetlands. In Liberation ecologies: environment, development, social movements, pp. 316-35, edited by R. Peet and M. Watts. New York: Routledge.

Carson, Rachel.

1994. Silent spring. New York: Houghton Mifflin Company. Original edition, 1962.

Castillo Nieto, Silvia.

1999. Sello azul certifica control de plaguicidas. El Financiero, 5/31/1999, 17.

Centre for Science and Environment.

2006. Poison vs nutrition: a briefing paper on pesticide contamination and food safety. New Delhi: Centre for Science and Environment.

Chan, Thomas Y.K.

2001. Vegetable-borne methamidophos poisoning. Clinical Toxicology 39 (4):337-8.

Chang, Ju-Mei, Tay-Hwa Chen, and Tony J. Fang.

2005. Pesticide residue monitoring in marketed fresh vegetables and fruits in central Taiwan (19992004) and an introduction to the HACCP system. Journal of Food and Drug Analysis 13 (4):368-76. 
Chaverri, Fabio.

1999. Importación y uso de plaguicidas en Costa Rica: Análisis del período 1994-1996. Heredia, Costa Rica: Instituto Regional de Estudios en Sustancias Tóxicas, Universidad Nacional de Costa Rica.

Chávez, César.

1993. Farm workers at risk. In Toxic struggles: The theory and practice of environmental justice, pp. 163-70, edited by R. Hofrichter. Philadelphia: New Society Publishers.

Conroy, Michael E., Douglas L. Murray, and Peter R. Rosset.

1996. A cautionary tail: Failed U.S. development policy and Central America. Boulder: Lynne Cook, Ian. Rienner Publishers.

Coulson, Justine.

2006. Geographies of food: Following. Progress in Human Geography 30 (5):655-66.

2004. Geographical knowledges in the Ecuadorian flower industry. In Geographies of commodity chains, pp. 139-55, edited by A. Hughes and S. Reimer. New York: Routledge.

Culliney, Thomas W., David Pimentel, and Marcia Pimentel.

1993. Pesticides and natural toxicants in foods. In The pesticide question: Environment, economics, and ethics, pp. 126-50, edited by D. Pimentel and H. Lehman. New York: Chapman and Hall.

Díaz-Knauf, Katherine, Carmen Ivankovich, Fernando Aguilar, Christine Bruhn, and Howard Schutz.

1993. Consumer attitudes toward food safety of produce in Costa Rica. Journal of Foodservice Systems 7 (2):105-15.

Dinham, Barbara.

1993. The pesticide hazard: a global health and environmental audit. Atlantic Highlands, New Jersey: Zed Books.

Dinham, Barbara.

2003. Growing vegetables in developing countries for local urban populations and export markets: Problems confronting small-scale producers. Pest Management Science 59 (5):575-82.

Dogheim, Salwa M., Eslam N. Nasr, Monir M. Almaz, and Mahmoud M. El-Tohamy.

1990. Pesticide residues in milk and fish samples collected from two Egyptian governates. Journal of the Association of Official Analytical Chemists 73 (1):19-21.

Dugger, Celia W.

2004. Supermarket giants crush Central American farmers. The New York Times, 28 December 2004.

DuPuis, E. Melanie.

2000. The body and the country: a political ecology of consumption. In New forms of consumption: consumers, culture, and commodification, pp. 131-152, edited by M. Gottdiener. Lanham, Maryland: Rowman \& Littlefield Publishers.

Ecobichon, Donald J. 2001. Pesticide use in developing countries. Toxicology 160 (1-3):27-33.

El Sebae, A.H.

1993. Special problems experienced with pesticide use in developing countries. Regulatory Toxicology and Pharmacology 17:287-91.

Environmental Protection Agency.

2004. Title 40: Protection of environment (Revised July 1, 2004). Environmental Protection Agency, [cited 14 September 2004]. Available from http://www.access.gpo.gov/nara/cfr/waisidx 04/40cfr180 04.html.

Environmental Protection Agency.

2007. Electronic Code of Regulations, Title 40: Protection of environment, part 180-tolerances and exemptions from tolerances for pesticide chemicals in food Environmental Protection Agency, [cited 6 November 2007]. Available from http://ecfr.gpoaccess.gov/.

Fairhead, James, and Melissa Leach.

1996. Misreading the African landscape: society and ecology in a forest-savanna mosaic. New York: Cambridge University Press.

Farley, T.A., and L. McFarland.

1999. Aldicarb as a cause of food poisoning-Louisiana, 1998. Morbidity and Mortality Weekly Report 48:269-71.

Fernandez-Cornejo, Jorge, Catherine Greene, Renata Penn, and Doris Newton.

1998. Organic vegetable production in the U.S.: certified growers and their practices. American Journal of Alternative Agriculture 13 (2):69-78.

Fernandez-Cornejo, Jorge, Sharon Jans, and Mark Smith.

1998. Issues in the economics of pesticide use in agriculture: a review of the empirical evidence. Review of Agricultural Economics 20 (2):462-88.

Food and Agriculture Organization.

2005. Codex alimentarius: pesticide residues in food. Food and Agriculture Organization. 
Galt, Ryan E.

2006. Political ecology and the pesticide paradox: markets, pesticide use, and human-environment relations in Costa Rican agriculture. Unpublished doctoral dissertation, Department of Geography, University of Wisconsin-Madison.

Galt, Ryan E.

2007. Regulatory risk and farmers' caution with pesticides in Costa Rica. Transactions of the

Galt, Ryan E. Institute of British Geographers 32 (3):377-94.

2008. Pesticides in export and domestic agriculture: reconceptualizing market orientation and

García, Jaime E. pesticide use in Costa Rica. Geoforum 39 (3):1378-1392.

1990. Residuos de plaguicidas en los alimentos: aspectos introductores. Tecnología en Marcha 10 (4):37-41.

García, Jaime E.

1997. Introducción a los plaguicidas. San José, Costa Rica: Editorial Universidad Estatal a Distancia.

García, Jaime E.

1999. El mito del manejo seguro de los plaguicidas en los países en desarrollo. Manejo Integrado de Plagas (52):25-41.

General Accounting Office.

1979. Better regulation of pesticide exports and pesticide residues in imported food is essential. Washington, D.C.: General Accounting Office.

Gockowski, James, and Michel Ndoumbe.

2004. The adoption of intensive monocrop horticulture in southern Cameroon. Agricultural Economics 30 (3):195-202.

Goodman, David, and E. Melanie DuPuis.

2002. Knowing food and growing food: beyond the production-consumption debate in the sociology of agriculture. Sociologia Ruralis 42 (1):5-22.

Green, Margaret A., Michael A. Heumann, H. Michael Wehr, Laurence R. Foster, L. Paul Williams, Jr., Jacquelyn A. Polder, Clarence L. Morgan, Sheldon L. Wagner, Lee A. Wanke, and James M. Witt. 1987. An outbreak of watermelon-borne pesticide toxicity. American Journal of Public Health 77 (11):1431-4.

Grossman, Lawrence S.

1998. The political ecology of bananas: contract farming, peasants, and agrarian change in the Eastern Caribbean. Chapel Hill: University of North Carolina Press.

Guan-Soon, Lim, and Ong Seng-Hock.

1987. Environmental problems of pesticide usage in Malaysian rice fields - Perceptions and future considerations. In Management of Pests and Pesticides: Farmers' Perceptions and Practices, pp.

Gupta, P. K. 10-21, edited by J. Tait and B. Napompeth. Boulder: Westview Press.

2004. Pesticide exposure--Indian scene. Toxicology 198 (1-3):83-90.

Guthman, Julie, and Melanie DuPuis, E. 2006.

Embodying neoliberalism: economy, culture, and the politics of fat. Environment and Planning D: Society and Space 24 (3):427-448.

Gutiérrez C., Fernando. 2003.

Intoxicados niños con agroquímico. La Nación, 29 October 2003.

Harrison, Jill Lindsey.

2006. 'Accidents' and invisibilities: scaled discourse and the naturalization of regulatory neglect in California's pesticide drift conflict. Political Geography 25 (5):506-29.

Hawkins, Keith.

1989. Rule and discretion in comparative perspective: the case of social regulation. Ohio State Law Journal 50:663-79.

Heong, K.L., M.M. Escalada, and A.A. Lazaro.

1995. Misuse of pesticides among rice farmers in Philippines. In Impact of Pesticides on Farmer Health and the Rice Environment, pp. 97-108, edited by P.L. Pingali and P.A. Roger. Norwell, Massachusetts and Los Baños, Philippines: Kluwer Academic Publishers and IRRI.

Heyman, Josiah McC.

1994. The organizational logic of capitalist consumption on the Mexico-United States border.

Research in Economic Anthropology 15:175-238.

Heyman, Josiah McC.

2005. The political ecology of consumption: beyond greed and guilt. In Political ecology across spaces, scales, and social groups, pp. 113-34, edited by S. Paulson and L.L. Gezon. New Brunswick: Rutgers University Press. 
Horst, Oscar H.

1987. Commercialization of traditional agriculture in highland Guatemala and Ecuador. Revista Geográfica del Instituto Panamericano de Geografía e Historia 106:5-18.

Hui, Xu, Qian Yi, Peng Bu-zhuo, Jiang Xiliu, and Hua Xiao-mei.

2003. Environmental pesticide pollution and its countermeasures in China. Ambio 32 (1):78-80.

Instituto Regional en Sustancias Tóxicas.

1999. Manual de plaguicidas: guía para América Central. Heredia, Costa Rica: Editorial de la Universidad Nacional.

Ip, Henrietta Man Hing.

1990. Chlorinated pesticides in foodstuffs in Hong Kong. Archives of Environmental Contamination

Irwin, Alan. and Toxicology 19 (2):291-6.

1995. Citizen science: a study of people, expertise, and sustainable development. New York: Routledge.

Jiménez, Jorge Norman.

1995. Plaguicidas y salud en las bananeras de Costa Rica. San José, Costa Rica: ASEPROLA.

Jungbluth, Frauke.

1997. Analysis of crop protection policy in Thailand. Thailand Development Research Institute Quarterly Review 12 (1):16-23.

Kannan, K., S. Tanabe, A. Ramesh, A. Subramanian, and R. Tatsukawa. 1992. Persistent organochlorine residues in foodstuffs from India and their implications on human dietary exposure. Journal of Agricultural and Food Chemistry 40 (3):518-24.

Kegley, Susan, Stephan Orme, and Lars Neumeister.

2000. Hooked on poison: Pesticide use in California, 1991-1998. San Francisco: Pesticide Action

Kopper, G. Network North America.

2002. Food safety perspectives in Costa Rica: Export and national markets for fresh produce. In Food safety management in developing countries, Proceedings of the International Workshop, CIRAD-FAO, 11-13 December 2000, pp. 1-4, edited by E. Hanak, E. Boutrif, P. Fabre and M. Pineiro. Montpellier, France: CIRAD-FAO.

La Gaceta (El Presidente de la República y los Ministros de Economía, Industria y Comercio, de Agricultura y Ganadería y de Salud).

1997. Límites máximos de residuos de plaguicidas en vegetales. Decreto Ejecutivo 26031-MEICMAG-S.

Le Heron, R., and M. Roche.

1999. Rapid reregulation, agricultural restructuring and the reimagining of agriculture in New Zealand. Rural Sociology 64 (2):203-18.

Leveridge, Yamillette R.

1998. Pesticide poisoning in Costa Rica during 1996. Veterinary and Human Toxicology 40 (1):424.

Lockie, Stewart, and Simon Kitto.

2000. Beyond the farm gate: production-consumption networks and agri-food research. Sociologia Ruralis 40 (1):3-19.

Lomborg, Bjørn.

2001. The skeptical environmentalist: Measuring the real state of the world. New York: Cambridge University Press.

Low, Nicholas, and Brendan Gleeson.

1998. Justice, society, and nature: an exploration of political ecology. New York: Routledge.

Marsden, Terry, Andrew Flynn, and Michelle Harrison.

McIntosh, Peggy. 1999. Consuming interests: the social provision of foods. London: UCL Press.

1988. White privilege and male privilege: a personal account of coming to see correspondences through work in women's studies. Wellesley College Center for Research on Women Working Paper 189. Wellesley, Massachusetts.

Medina, Charito P.

1987. Pest control practices and pesticide perceptions of vegetable farmers in Loo Valley, Benguet, Philippines. In Management of pests and pesticides: Farmers' perceptions and practices, pp. 150-7, edited by J. Tait and B. Napompeth. Boulder: Westview Press.

Mo, Claudette Lee. 2001. Environmental impact of leatherleaf fern farms in Costa Rica. Doctoral Dissertation, Land Resources, University of Wisconsin-Madison.

Mukherjee, Irani.

2003. Pesticides residues in vegetables in and around Delhi. Environmental Monitoring and Assessment 86 (3):265-71. 
Murdoch, Jonathan, Terry Marsden, and Jo Banks.

2000. Quality, nature, and embeddedness: Some theoretical considerations in the context of the food sector. Economic Geography 76 (2):107-25.

Murray, Douglas L.

1991. Export agriculture, ecological disruption, and social inequity: Some effects of pesticides in southern Honduras. Agriculture and Human Values 8 (4):19-29.

Murray, Douglas L.

1994. Cultivating crisis: The human cost of pesticides in Latin America. Austin: University of Texas Press.

Murray, Douglas L., and Polly Hoppin.

1992. Recurring contradictions in agrarian development: Pesticide problems in Caribbean Basin nontraditional agriculture. World Development 20 (4):597-608.

Murray, Douglas L., and Peter Leigh Taylor.

2000. Claim no easy victories: evaluating the pesticide industry's global safe use campaign. World Development 28 (10):1735-49.

Nauen, Ralf, and Thomas Bretschneider.

2002. New modes of action of insecticides. Pesticide Outlook 13:241-5.

Navarro, Patricia, and Marvin Barquero.

1990. Nadie controla residuos en hortalizas: Sólo un laboratorio analiza alimentos, distribuidores dicen que cumplen ley. La Nación, 11/14/1990, 5A.

Opondo, Mary Magdalene.

2000. The socio-economic and ecological impacts of the agro-industrial food chain on the rural economy in Kenya. Ambio 29 (1):35-41.

Orme, S., and S. Kegley.

2006. PAN pesticide database [Internet database]. Pesticide Action Network, North America, [cited October 10, 2004 to July 8, 2006]. Available from http://www.pesticideinfo.org.

Pollan, Michael.

2006. The omnivore's dilemma: a natural history of four meals. New York: Penguin Books.

Porter, Warren P., James W. Jaeger, and Ian H. Carlson.

1999. Endocrine, immune, and behavioral effects of aldicarb (carbamate), atrazine (triazine) and nitrate (fertilizer) mixtures at groundwater concentrations. Toxicology and Industrial Health 15 (12):133-50.

Probst, Kirsten, L. Pülschen, J. Sauerborn, and C.P.W. Zebitz.

1999. Influencia de varios regímenes de uso de plaguicidas sobre la entomofauna de tomate en las tierras altas de Ecuador. Manejo Integrado de Plagas (54):53-62.

Pulido, Laura.

2000. Rethinking environmental racism: White privilege and urban development in Southern California. Annals of the Association of American Geographers 90 (1):12-40.

Reardon, Thomas, and Christopher B. Barrett.

2000. Agroindustrialization, globalization, and international development: an overview of issues, patterns, and determinants. Agricultural Economics 23 (3):195-205.

Reardon, Thomas, J-M. Codron, L. Busch, J. Bingen, and C. Harris.

2001. Global change in agri-food grades and standards: agribusiness strategic responses in developing countries. International Food and Agribusiness Management Review 2 (3/4):421-5.

Robbins, Paul.

2003. Beyond ground truth: GIS and the environmental knowledge of herders, professional foresters, and other traditional communities. Human Ecology 31 (2):233-53.

Rodríguez Navarro, Luis Diego.

1983. Determinación de residuos del insecticida methamidophos (o,s-dimetil-fosforamidotioato) en lechuga. Ingeniero Agrónomo, Facultad de Agronomía, Universidad de Costa Rica, San José, Costa Rica.

Rodríguez Solano, José Armando.

1994. Programa de monitoreo de residuos de plaguicidas en muestras de vegetales destinadas al consumo nacional. San José, Costa Rica: Laboratorio de Residuos de Plaguicidas, Departamento de Abonos y Plaguicidas, Dirección General de Sanidad Vegetal, M.A.G.

Rojas, José Enrique.

2004. 61 niños intoxicados con plaguicida. La Nación, 15 May 2004.

Russell, Edmund.

2001. War and nature: fighting humans and insects with chemicals from World War I to Silent

Sass, Robert. Spring. New York: Cambridge University Press.

2000. Agricultural "killing fields": the poisoning of Costa Rican banana workers. Environmental and Occupational Health 30 (3):491-514. 
Schwab, Arnold.

1995. Pesticides - aid to agriculture or poison - and the conflicting role of the development worker. In Pesticides in Tropical Agriculture: Hazards and Alternatives, pp. 107-47, edited by R. Scoones, I. Altenburger. Weikersheim, Germany: Margraf Verlag.

1999. New ecology and the social sciences: what prospects for a fruitful engagement? Annual Review of Anthropology 28:479-507.

Secretaría Ejecutiva de Planificación Sectoral Agropecuaria (SEPSA).

2004. Costa Rica: Boletín Estadístico Agropecuario Nacional $N^{\circ}$ 15. San José, Costa Rica: Secretaría Ejecutiva de Planificación Sectoral Agropecuaria.

Stewart, Sarah.

1996. The price of a perfect flower: Environmental destruction and health hazards in the Colombian flower industry. In Green guerrillas: Environmental conflicts and initiatives in Latin America and the Caribbean, pp. 132-9, edited by H. Collinson. London: Latin American Bureau.

Stonich, Susan C.

1993. I am destroying the land!: The political ecology of poverty and environmental destruction in Honduras. Boulder: Westview Press.

Szasz, Andrew.

2007. Shopping our way to safety: how we changed from protecting the environment to protecting ourselves. Minneapolis: University of Minnesota Press.

Thrupp, Lori Ann.

1991a. Long-term losses from accumulation of pesticide residues: A case of persistent copper toxicity in soils of Costa Rica. Geoforum 22 (1):1-15.

Thrupp, Lori Ann.

1991b. Sterilization of workers from pesticide exposure: The causes and consequences of DBCPinduced damage in Costa Rica and beyond. International Journal of Health Services 21 (4):731-57.

Thrupp, Lori Ann, Gilles Bergeron, and William F. Waters.

1995. Bittersweet harvests for global supermarkets: Challenges in Latin America's agricultural export boom. Washington, D.C.: World Resources Institute.

Valverde Gómez, Edgar, Elizabeth Carazo Rojas, and Lizbeth Araya Rojas. 2001. Manipulación, consumo y residuos de plaguicidas en hortalizas y frutas. San José, Costa Rica: Organización Panamericana de la Salud (OPS).

Vandermeer, John H., and Ivette Perfecto. 1995. Breakfast of biodiversity: the truth about rain forest destruction. Oakland, California: Institute for Food and Development Policy.

Walker, Peter A.

2005. Political ecology: where is the ecology? Progress in Human Geography 29 (1):73-82.

Wallerstein, Immanuel Maurice.

1974. The modern world-system. New York: Academic Press.

Wargo, John.

1998. Our children's toxic legacy: How science and law fail to protect us from pesticides. Second ed. New Haven: Yale University Press.

Watts, Michael.

1983. Hazards and crisis: a political economy of drought and famine in northern Nigeria. Antipode 15 (1):24-34.

Weir, David, and Constance Matthiessen.

1989. Will the circle be unbroken? Mother Jones, June, 20-7.

Weppner, Sarah, Kai Elgethun, Chensheng Lu, Vince Hebert, Michael Yost, and Richard A. Fenske.

2005. The Washington aerial spray drift study: Children's exposure to methamidophos in an agricultural community following fixed-wing aircraft applications. Journal of Exposure Analysis and Environmental Epidemiology:1-10.

Wesseling, Catharina, Anders Ahlbom, Daniel Antich, Ana Cecelia Rodríguez, and Roberto Castro. 1996. Cancer in banana plantation workers in Costa Rica. International Journal of Epidemiology 25 (6):1125-31.

Whorton, James C.

1974. Before Silent Spring: pesticides and public health in pre-DDT America. Princeton: Princeton University Press.

Wilk, Richard.

2006. "But the young men don't want to farm any more": political ecology and consumer culture in Belize. In Reimagining political ecology, pp. 149-70, edited by A. Biersack and J.B. Greenberg. Durham: Duke University Press.

Wolf, Eric R.

1982. Europe and the people without history. Berkeley: University of California Press. 
Wolf, Steven, Brent Hueth, and Ethan Ligon. 2001. Policing mechanisms in agricultural contracts. Rural Sociology 66 (3):359-81.

Wu, Ming-Ling, Jou-Fang Deng, Wei-Jen Tsai, Jiin Ger, Sue-Sun Wong, and Hong-Ping Li. 2001. Food poisoning due to methamidophos-contaminated vegetables. Clinical Toxicology 39 (4):333-6.

Wynne, Brian.

1989. Frameworks of rationality in risk management: towards the testing of naïve sociology. In Environmental threats: Perception, analysis and management, pp. 33-47, edited by J. Brown. New York: Belhaven Press.

Yen, Ivan Chang, Isaac Bekele, and Carlyle Kalloo.

1999. Use patterns and residual levels of organophosphate pesticides on vegetables in Trinidad, West Indies. Journal of the Association of Official Analytical Chemists 82 (4):991-5.

Zaidi, Iqtidar $\mathrm{H}$.

1984. Farmers' perception and management of pest hazard. Insect Science and Its Applications 5 (3):187-201.

Zimmerer, Karl S.

1991. Wetland production and smallholder persistence: agricultural change in a highland Peruvian region. Annals of the Association of American Geographers 81 (3):443-63.

Zimmerer, Karl S.

1996. Ecology as cornerstone and chimera in human geography. In Concepts in human geography, pp. 161-88, edited by C. Earle, K. Mathewson and M.S. Kenzer. London: Rowman and Littlefield.

\begin{abstract}
This paper addresses pesticide residues on vegetables in developing countries through the specific case of Costa Rica. Pesticide residues are often very high on vegetables in developing countries, generally considerably higher than in industrialized countries. Using a political ecology approach, I combine qualitative and quantitative primary data with secondary data to answer two questions. Why do farmers use pesticides in a manner that results in high levels of residues on vegetables? And, how do markets with unequal regulatory strength affect farmers' pesticides use, and, by inference, the resulting exposure of different populations fed by different market segments? While usually attributed to farmer ignorance, I argue that the pesticide residue problem arises from a triad of causes: higher efficacy of more residual and toxic pesticides, combined with many vegetables' biological trait of consecutive harvests, and a volatile vegetable market upon which farm household reproduction depends. With high input costs and low farm gate prices, farmers in markets with minimal regulation will use more residual and toxic pesticides. Using the idea of a double standard, I show that lax regulation in the open national market means that farmers are less cautious about residues on national market produce than export produce, and that some export farmers use the open national market as an outlet for their produce when they use highly residual pesticides. Uneven regulations between North and South are manifested in farmer's management decisions, and lead to the injustice of higher residues in developing country vegetables.
\end{abstract}

Keywords: pesticide residues; pesticide use; uneven regulation; Costa Rica; developing countries; national market vegetables; export vegetables; environmental injustice

\title{
Résumé
}

Cet article porte sur les résidus de pesticides sur les légumes dans les pays en voie du développement, à travers le cas du Costa Rica. Les résidus de pesticides sont beaucoup plus élevé dans le 'tiers monde'. A travers une approche "political ecology", pour répondre à deux questions je combine pluiseurs données qualitative et quantitative. Pourquoi les agriculteurs utilisent les pesticides d'une manière qui entraîne des niveaux élevés de résidus sur les légumes? Et, comment l'inégalité de la réglementation des marchés influencer des agriculteurs utilisent les pesticides, et, par déduction, l'exposition résultant des différentes populations alimenté par les différents segments de marché? Bien que généralement attribuée à l'ignorance des exploitants, je démontrerai que le problème des résidus de pesticides à partir d'une triade de causes: 1) l'efficacité supérieure des pesticides plus toxiques, 2) le fait que nombreux legumes sont récoltés consécutivement, 3) le marché, sur lequel repose la reproduction des ménages agricoles, est volatile. Il y a donc un double standard; je montre que la mauvaise réglementation nationale signifie que les agriculteurs sont moins prudents sur les résidus de pesticides sur les cultures vendu national. Produire de l'exportation est plus strictement réglementée, et certains agriculteurs utilisent des exportations sur le marché national comme un point de vente whenpesticide résidus sont élevés. Réglementation inégale entre le Nord et le Sud sont manifestés dans les décisions prises par les agriculteurs, et conduire à une injustice - il existe des niveaux plus élevés de pesticides dans les legumes vendus dans des pays en voie du développement.

Mots-clés: les résidus de pesticides, l'utilisation des pesticides; réglementation inégale; Costa Rica; les pays en développement; marché national des légumes, les légumes d'exportation; injustice environnemental. 


\section{Resumen}

Mediante el caso específico de Costa Rica, este documento aborda los residuos de plaguicidas en hortalizas en los países en desarrollo. Los residuos de plaguicidas suelen ser muy altos en hortalizas en los países en desarrollo, considerablemente mas altos que en los países industrializados. Utilizando un enfoque de la ecología política, combino datos primarios del tipo cualitativo y cuantitativo con datos secundarios para contestar dos preguntas. ¿Por qué los agricultores usan los plaguicidas en una manera que resulta en niveles altos de residuos de plaguicidas en las hortalizas? Y, ¿cómo los mercados con fuerza desigual de regulación afectan al uso de plaguicidas por los agricultores, y, por inferencia, la exposición resultante de las diferentes poblaciones alimentadas por los diferentes segmentos del mercado? Si bien generalmente atribuidos a la ignorancia de los agricultores, yo sostengo que el problema de residuos de plaguicidas se deriva de una tríada de causas: mayor eficacia de los plaguicidas más tóxicos y residuales, junto con el rasgo biológico de cosechas consecutivas de muchas hortalizas, y un mercado volátil de hortalizas en lo que los hogares agrícolas depende de reproducción. Con costos altos de los insumos y bajos precios agrícolas, los agricultores en los mercados con un mínimo de regulación se utilizan plaguicidas más residuales y tóxicos. Utilizando la idea de un doble rasero, muestro que la laxitud de la regulación en el mercado nacional abierto significa que los agricultores tienen menos cuidado con residuos en productos para el mercado nacional que los productos para exportación. Algunos agricultores de exportación usan el mercado nacional como una salida para sus productos cuando usan los plaguicidas muy residuales. Reglamentos desigual entre el Norte y el Sur se manifiestan en las decisiones de manejo de agricultores, y causan la injusticia de los residuos más altos en hortalizas consumidas en los países en desarrollo.

Palabras clave: residuos de plaguicidas; uso de plaguicidas; regulación desigual; Costa Rica; los países en desarrollo; hortalizas para el mercado nacional; hortalizas para exportación; injusticia ambiental 